\title{
A bal kamra korszerü echokardiográfiás vizsgálata - az M-módtól a 3D speckle-tracking képalkotásig
}

\author{
Nemes Attila dr. - Forster Tamás dr. \\ Szegedi Tudományegyetem, Általános Orvostudományi Kar, Szent-Györgyi Albert Klinikai Központ, \\ II. Belgyógyászati Klinika és Kardiológiai Központ, Szeged
}

\begin{abstract}
A bal kamrának alapvető szerepe van a szervezet vérkeringésének fenntartásában, ezért annak noninvazív vizsgálata esszenciális fontosságú. A jelen összefoglaló közlemény célja a jelenleg elérhetô, a bal kamra vizsgálatában használatos echokardiográfiás módszerek klinikai jelentőségének bemutatása, kiemelve a legkorszerúbbnek tartott háromdimenziós (és) speckle-tracking eljárások fontosságát. Orv. Hetil., 2015, 156(43), 1723-1740.
\end{abstract}

Kulcsszavak: bal kamra, funkció, echokardiográfia

\section{Recent echocardiographic examination of the left ventricle - from M-mode to $3 \mathrm{D}$ speckle-tracking imaging}

\begin{abstract}
The left ventricle has a vital role in maintaining circulation of the body, therefore, its non-invasive assessment is essential. The aim of the present review is to demonstrate clinical relevance of different echocardiographic methods in the evaluation of left ventricle emphasizing the importance of the most recent three-dimensional (and) speckletracking methodologies.
\end{abstract}

Keywords: left ventricle, function, echocardiography

Nemes, A., Forster, T. [Recent echocardiographic examination of the left ventricle - from M-mode to 3D speckletracking imaging]. Orv. Hetil., 2015, 156(43), 1723-1740.

(Beérkezett: 2015. július 15.; elfogadva: 2015. augusztus 26.)

\section{Rövidítések}

$2 \mathrm{D}$ = kétdimenziós; 2DE = kétdimenziós echokardiográfia; 2DSTE = kétdimenziós speckle-tracking echokardiográfia; $3 \mathrm{D}=$ háromdimenziós; 3DS = háromdimenziós strain; 3DSTE = háromdimenziós speckle-tracking echokardiográfia; $\mathrm{A}=\mathrm{a}$ mitralis beáramlás második hulláma diasztoléban; $\mathrm{A}^{\prime}=$ a pitvari kontrakció sebességértéke (TDI-vel mérve); $\mathrm{AA}=$ bal kamrai apicalis anterior szegmentum; $\mathrm{AAL}=$ bal kamrai apicalis anterolateralis szegmentum; AAS = bal kamrai apicalis anteroseptalis szegmentum; ACT $=($ acceleration time $)$ akcelerációs idő; $\mathrm{AI}=$ bal kamrai apicalis inferior szegmentum; $\mathrm{AIL}=$ bal kamrai apicalis inferolateralis szegmentum; AIS = bal kamrai apicalis inferoseptalis szegmentum; $\mathrm{Am}=\mathrm{a}$ pitvari kontrakció sebességértéke (TDI-vel mérve); Ap = apex; $\mathrm{AP} 2 \mathrm{CH}=($ apical 2 -chamber view) csúcsi 2 üregi nézet; $\mathrm{AP} 3 \mathrm{CH}=$ (apical 3-chamber view) csúcsi 3 üregi nézet; $\mathrm{AP} 4 \mathrm{CH}=$ (apical 4-chamber view) csúcsi 4 üregi nézet; AS = area strain; ASDI = (area strain dyssynchrony index) 3DSTE-vel mérhető diszszinkróniaparaméter; $\mathrm{BA}=$ bal kamrai basalis anterior szegmentum; $\mathrm{BAL}=$ bal kamrai basalis anterolateralis szegmentum; $\mathrm{BAS}=$ bal kamrai basalis anteroseptalis szegmentum; BI = bal kamrai basalis inferior szegmentum; BIL = bal kamrai basalis inferolateralis szegmentum; BIS = bal kamrai basalis inferoseptalis szegmentum; $\mathrm{BK}=$ bal kamra; $\mathrm{CRT}=$ (cardiac resynchronization therapy) kardiális reszinkronizációs kezelés; CS = circumferentialis strain; $\mathrm{D}=$ (diameter) átmérö; $\mathrm{DE}=$ Doppler-echokardiográfia; DLC $=$ (delayed longitudinal contraction) TDI-vel mérhető diszszinkróniaparaméter; $\mathrm{dP}=$ nyomáskülönbség; dt = időkülönbség; $\mathrm{DT}=($ deceleration time $)$ a mitralis E-hullám-deceleratio ideje Dopplerrel mérve; 
$\mathrm{E}=$ a mitralis beáramlás első hulláma diasztoléban; E' = korai kamrai csúcs diasztolés sebesség (TDI-vel mérve); Em = korai kamrai csúcs diasztolés sebesség (TDI-vel mérve); EDA = (end-diastolic area) bal kamrai végdiasztolés area; EDD = (end-diastolic diameter) bal kamrai végdiasztolés átmérő; $\mathrm{EDV}=$ (end-diastolic volume) bal kamrai végdiasztolés térfogat; $\mathrm{EF}$ = bal kamrai ejekciós frakció; $\mathrm{EKG}=$ elektrokardiográfia; $\mathrm{EPSS}=($ mitral E point to septal separation $)$ MME-vel mérhető diszszinkróniaparaméter; ESA = (end-systolic area) bal kamrai végszisztolés area; $\mathrm{ESD}=$ (end-systolic diameter) bal kamrai végszisztolés átmérő; ESV = (end-systolic volume) bal kamrai végszisztolés térfogat; $\mathrm{ET}=$ (ejection time) ejekciós idő; FAC = (fractional area change) bal kamrai frakcionális areaváltozás; FS = (fractional shortening) bal kamrai frakcionális rövidülés; GLS = globális longitudinális strain; IVCT $=($ isovolumetric contraction time) izovolumetrikus kontrakciós idő; IVMD $=$ (interventricular mechanical delay) DE-vel mérhetó diszszinkróniaparaméter; IVRT $=$ (isovolumetric relaxation time) izovolumetrikus relaxációs idő; IVS = interventricularis septum; JK = jobb kamra; $\mathrm{L}=$ két pont közötti távolság; $\mathrm{L}_{\mathrm{t}}=$ egy adott $\mathrm{t}$ időpontban mért hossz; $\mathrm{L}_{0}=\mathrm{az}$ eredeti hossz a 0 időpontban; $\mathrm{L}_{\mathrm{D}}=$ végdiasztolés myocardialis hossz; $\mathrm{L}_{\mathrm{S}}=$ végszisztolés myocardialis hossz; LLWC $=($ left lateral wall contraction) DE-vel mérhető diszszinkróniaparaméter; LPEI = (left ventricular preejection interval) DE-vel mérhető diszszinkróniaparaméter; LS = longitudinális strain; LVFT/RR = (left ventricular filling time, cardiac cycle length) DE-vel mérhetö diszszinkróniaparaméter; $\mathrm{LVM}=$ (left ventricular mass) bal kamrai izomtömeg; LVOT $=$ (left ventricular outflow tract) bal kamrai kifolyótraktus; $\mathrm{MA}=$ bal kamrai midanterior szegmentum; $\mathrm{MAL}=$ bal kamrai midanterolateralis szegmentum; MAPSE $=($ mitral annular plane systolic excursion $)$ a mitralis anulus síkjának szisztolés előremozdulása; MAS = bal kamrai midanteroseptalis szegmentum; $\mathrm{MI}=$ bal kamrai midinferior szegmentum; MIL = bal kamrai midinferolateralis szegmentum; MIS = bal kamrai midinferoseptalis szegmentum; $\mathrm{MME}=$ M-mód echokardiográfia; MPI = myocardial performance index (Tei-index $) ; M R I=($ magnetic resonance imaging $)$ mágneses rezonanciás vizsgálat; $\mathrm{PVD}=$ (peak velocity difference) TDI-vel mérhetô diszszinkróniaparaméter; $\mathrm{PW}=$ (posterior wall) a bal kamra hátsó fala; RDI = (rotációs diszperziós index $)$ 3DSTE-vel mérhető diszszinkróniaparaméter; RS = radialis strain; RT3DE = (real-time three-dimensional echocardiography) real-time háromdimenziós echokardiográfia; RWT = (relative wall thickness) relatív falvastagság; $S^{\prime}=$ bal kamrai csúcs szisztolés sebesség (TDI-vel mérve); $\mathrm{SD}=$ standard deviáció; SDI $=($ systolic dyssynchrony index $)$ szisztolés diszszinkrónia index; $\mathrm{SHI}=$ (second harmonic imaging $)$ felharmonikus képalkotás; $S \mathrm{~m}=$ bal kamrai csúcs szisztolés sebesség (TDI-vel mérve); SPWMD = (septal-posterior wall motion delay) MME-vel mérhető diszszinkróniaparaméter; STE = speckle-tracking echokardiográfia; SV = (stroke volume) ütötérfogat; Ts = a szisztolés csúcssebesség eléréséhez szükséges idő; TDI = (tissue Doppler echocardiography) szöveti Doppler-echokardiográfia; TMSV $=$ (time-to-minimum systolic volume) a minimális szisztolés térfogat eléréséhez szükséges ido”; TPSS $=$ (time-to-peak systolic strain) a szisztolés csúcsstrain eléréséhez szükséges idő; $V_{1}$ és $V_{2}=$ két különböző pontban mért sebességérték; $\mathrm{V}_{\max }=$ maximális áramlási sebesség; $\mathrm{VVI}=$ velocity vector imaging; WMS = (wall motion score) falmozgásscore; WMSI = (wall motion score index $)$ falmozgásscoreindex

\section{Bal kamra}

A bal kamra (BK) a szív bal oldalán elhelyezkedő, tojáshoz hasonló alakú szívüreg, amelynek belfelszíne az izomgerendáknak és az innen eredő papillaris izmoknak megfelelően egyenetlen. Egészségesekben szisztolé során a $\mathrm{BK}$ a semilunaris aortabillentyưn keresztül az ascendáló aorta fele ürül zárt mitralis billentyű mellett, míg telődése diasztoléban a bal pitvar felől a mitralis (vagy bal bicuspidalis/atrioventricularis) billentyưn keresztül valósul meg zárt aortabillentyú mellett [1].

Ahhoz, hogy képalkotó vizsgálat során egy adott szív BK-ját megfelelő módon jellemezni tudjuk, a mai elvárásoknak megfelelően az alábbi információk megismerése fontos:

- Vizsgálataink során le kell mérnünk a BK szisztolés és diasztolés méreteit, átmérőit, lehetőség szerint térfogatértékeit, figyelembe véve a szívüreg sajátos egyéni belfelületét és alakját [2] (1. táblázat).

- Pontos és reprodukálható méréseket kell végeznünk abból a célból, hogy megismerjük a BK szegmentumainak falvastagságát és annak szimmetricitását [2].

- Amennyiben a BK funkciójára vagyunk kíváncsiak, a pumpafunkcióját jellemző paraméterek tisztázása mellett a falmozgások kvalitatív és kvantitatív jellemzőit, illetve egyéb funkcionális paramétereket kell lemérnünk [2].

- Normális esetben szisztoléban a BK basalis része az óramutató járásával megegyező, míg csúcsa azzal ellentétes irányú rotáló mozgást végez, amely két mozgásnak a nettó eredője a BK-i csavarodás, az úgynevezett BK-i twist (a BK-i torzió a BK-i twist és a BK hosszának hányadosa). Diasztoléban, elsősorban az izovolumetrikus relaxáció alatt, mielőtt a mitralis billentyü kinyílik, a BK visszatér eredeti állapotába (ezt nevezzük untwistnek). A BK falrészleteinek szívciklus szerinti vastagodása és vékonyodása mellett ennek a facsaró-csavaró jellegú mozgásnak a kvantitatív jellemzése is fontos, mivel fiziológiai tanulmányok szerint a pumpafunkció jelentôs hányadáért ez a mozgásforma felel [3].

- A fentiek mellett klinikai jelentőséggel bír a BK-i myocardialis szegmentumok mozgásának szinkronicitása. A jelenleg elérhető szakmai irányelvekben rögzítettek szerint szívelégtelen betegekben megfelelő panaszok

1. táblázat | Echokardiográfiás bal kamrai normálértékek

\begin{tabular}{lll}
\hline & Nő & Férfi \\
\hline BK-i végdiasztolés átmérő $(\mathrm{mm})$ & $39-53$ & $42-59$ \\
BK-i végdiasztolés térfogat $(\mathrm{ml})$ & $56-104$ & $67-155$ \\
BK-i végszisztolés térfogat $(\mathrm{ml})$ & $19-49$ & $22-58$ \\
BK-i ejekciós frakció $(\%)$ & $\geq 55$ & $\geq 55$ \\
BK-i izomtömeg $(\mathrm{g})$ & $66-150$ & $96-200$ \\
\hline
\end{tabular}

$\mathrm{BK}=$ bal kamra 
és EKG-eltérések detektálása esetén jöhet szóba cardialis reszinkronizációs kezelés (cardiac resynchronization therapy - CRT) [4]. Ismert tény azonban, hogy CRT ellenére a betegek 30\%-a nonreszpondernek bizonyul (vagyis a kezelés hatástalan), így joggal merül fel az igény olyan, akár képalkotó diagnosztika során detektálható paraméterekre, amelyek a betegek megfelelőbb szelekciójára alkalmasak.

Jelenleg az echokardiográfia a legszélesebb körben alkalmazott képalkotó diagnosztikus eljárás a $\mathrm{BK}$ részletes noninvazív vizsgálatára. Ma már azonban számos echokardiográfiás módszertan létezik, amelyek ismerete esszenciális fontosságú a cardiovascularis képalkotásban dolgozók számára. Mivel a napi rutin részét a $\mathrm{BK}$ morfológiai és funkcionális megítélése jelenti, a klinikumban leggyakrabban alkalmazott M-módú, kétdimenziós, Doppler- és szöveti Doppler-echokardiográfiás módszereket csillaggal kiemeltük, de igyekeztünk bemutatni a ma már széleskörúen nem alkalmazott, de elérhető lehetőségek mellett az újabb speckle-tracking és/vagy háromdimenziós echokardiográfiás fejlesztéseket is.

\section{M-mód echokardiográfia (MME)}

Az M-mód echokardiográfia (MME) az egyik legrégebben alkalmazott echokardiográfiás eljárás, kivitelezése egyszerü, gyors, rutinszerüen alkalmazható és jó minőségben reprodukálható. MME során egy adott síkban az idő függvényében vizsgáljuk a BK-t, majd a rögzített képen a szívciklusnak megfelelően méréseket végzünk [5].

\section{* A bal kamrai méretek és térfogatok mérése}

MME során a BK átmérőjét (D) a mitralis billentyü vitorlacsúcsának a szintjében, a BK hossztengelyére merőlegesen, végszisztoléban és végdiasztoléban mérjük (1. ábra) [2]. A mérések történhetnek parasternalis hossztengelyi mellett rövid tengelyi nézetben is (Teichholz-féle módszer) [6]. A módszer előnye, hogy relatíve jól reprodukálható, magas az időbeli felbontóképesség, és számos közlemény áll a módszertan használhatósága mellett. Nehézséget okozhat, ha az ultrahangnyaláb iránya nem megfelelő, és azzal is tisztában kell lennünk, hogy az MME alaptermészeténél fogva „egydimenziós” vizsgálatot tesz lehetővé. A BK-i térfogatok számítási lehetőségeiről logikai okokból a következő fejezetben lesz szó.

\section{A bal kamra funkciójának jellemzése}

\section{*Ejekciós frakció (EF) mérése}

A BK-EF mérése a napi rutin része, a legtöbbet kért és számított echokardiográfiás paraméter. Számítása többféle módszerrel lehetséges (lásd később!). Bár az EF mérési pontossága nagy eltéréseket mutathat és függ attól,

*-gal jelöljük a rutinban alkalmazott módszereket. mely módszerrel mérjük, gyakorlott-e a szonográfus, alkalmazunk-e echokardiográfiás kontrasztanyagot stb., a paraméter elfogadottsága egyelőre megkérdőjelezhetetlen. Ennek oka abban rejlik, hogy számos tanulmány igazolta az echokardiográfiával mért EF prognosztikus értékét szívelégtelenségben, myocardialis infarctust követóen és egyéb kórképekben $[7,8]$. MME során az alábbiak ismerete fontos az EF számításakor:

A térfogatértékek birtokában az EF az alábbi képlet segítségével számítható: $\mathrm{EF}=(\mathrm{EDV}-\mathrm{ESV}) / \mathrm{EDV} \times 100$, ahol az EDV és ESV a végdiasztolés és végszisztolés BK-i térfogatot jelöli [5]. A Cube-formula segítségével, a nevének megfelelően, „köbösítve” számítjuk az EF-et: $\mathrm{EF}=\left(\mathrm{EDD}^{3}-\mathrm{ESD}^{3}\right) / \mathrm{EDD}^{3} \times 100$. Ilyenkor a BK idealizált alakja egy ellipszoid idom, amelynek hossztengelye kétszerese a rövid tengelynek és alapja kör alakú $\left(\mathrm{V}=\Pi / 3 \times \mathrm{D}^{3}\right.$, egyszerüsítve $\left.\mathrm{V}=\mathrm{D}^{3}\right)$. A Teichholz-féle formula esetén: $\mathrm{V}=7 /(2,4+\mathrm{D}) \times \mathrm{D}^{3}$ [9]. További lehetőség a módosított Quinones-féle formula használata: $\mathrm{EF}_{\text {kalkulált }}=\left(\mathrm{EDD}^{2}-\mathrm{ESD}^{2}\right) / \mathrm{EDD}^{2} \times 100 . \mathrm{Az} \quad \mathrm{EF}_{\text {kalkulált }}$ mellett figyelembe vesz egy faktort is: $\mathrm{EF}=\mathrm{EF}_{\text {kalkulált }}{ }^{+}$ $\left[\left(1-\mathrm{EF}_{\text {kalkulált }}\right) \times(\% \Delta \mathrm{L})\right.$, ahol a $\% \Delta \mathrm{L}$ normális $\mathrm{BK}$ esetén $+15 \%$, míg egyéb falmozgások esetén az alábbiak szerint számolunk: hypokinesis $(+5 \%)$, akinesis $(0 \%)$, dyskinesis $(-5 \%)$ vagy aneurysma $(-15 \%)$.

A jelenleg elérhető szakmai irányelveknek megfelelően a Teichholz- és Quinones-módszertanok nem ajánlottak a BK vizsgálatára [2]. Az EF normálértéke $\geq 55 \%$, enyhén csökkent, amennyiben 45-54\%, közepesen csökkent, ha értéke 30-44\% közötti, míg súlyos elégtelenségről akkor beszélünk, ha $<30 \%$.

A mért átmérőadatok birtokában a frakcionális rövidülés (fractional shortening - FS) értéke is meghatározható (korábban lineáris EF-nek is nevezték): FS = (EDDESD)/EDD, ahol az EDD és ESD a végdiasztolés és végszisztolés BK-átmérő (normálérték: 25-40\%) [5].

* Mitral annular plane systolic excursion (MAPSE) Apicalis 4 üregi nézetben (apical 4-chamber view $\mathrm{AP} 4 \mathrm{CH})$ az ultrahangnyalábot a lateralis mitralis anulusra helyezve annak longitudinális mozgása az idő függvényében vizsgálható (normálérték: $>1 \mathrm{~cm}$ ) [2, 10].

Egyéb, a klinikumban már kevésbé használt módszerek

Mitral E point to septal separation (EPSS)

Amennyiben az M-módot a mitralis billentyú anterior vitorlájának hegyére tesszük, akkor annak mozgása parasternalis hosszmetszeti nézetben követhető. Az Mmód felvételen normálisan a mitralis beáramlást jellemző első, úgynevezett E-hullám maximuma és a septum távolsága $<6 \mathrm{~mm}$ (E point to septal separation - EPSS). Csökkent BK-funkció esetén értéke megnövekedett [11].

Az aorta billentyưmozgásának elemzése

Csökkent BK-i ütótérfogat (stroke volume - SV) esetén végszisztolé idején az áramlás lecsökken, ami az aorta- 


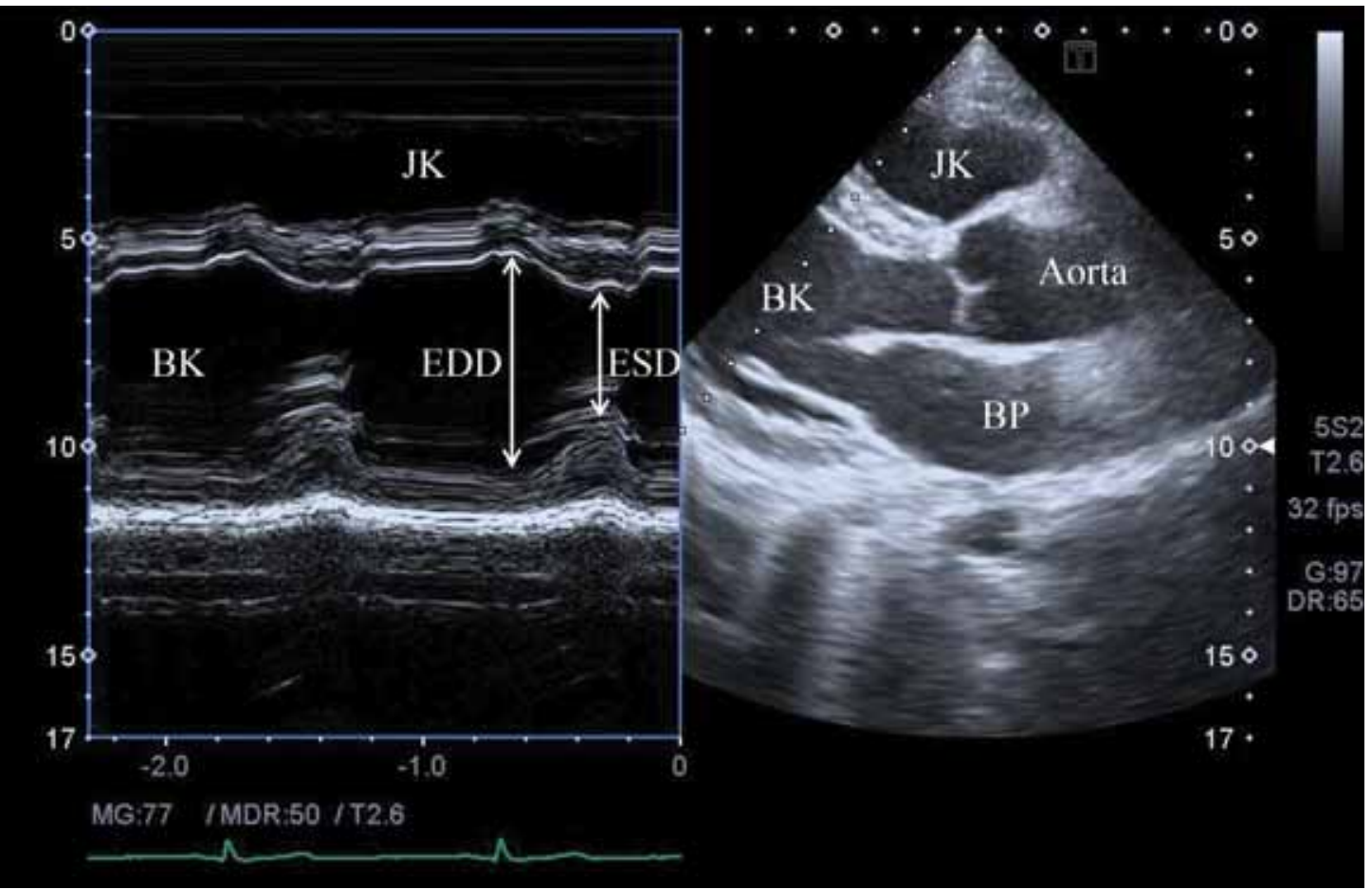

1. ábra

A bal kamra vizsgálata M-mód echokardiográfia segítségével parasternalis hossztengelyi nézetben 2 dimenziós echokardiográfia vezérlésével. Az interventricularis septum, a bal kamra üregi átmérője és a hátsó fal vastagsága direkt módon mérhető a szívciklusnak megfelelően szisztoléban és diasztoléban. Speciális szoftver segítségével a mért értékekből bal kamrai volumetrikus paraméterek, izomtömeg és ejekciós frakció számítható

$\mathrm{BK}$ = bal kamra; $\mathrm{BP}$ = bal pitvar; $\mathrm{EDD}$ = bal kamrai végdiasztolés átméró; $\mathrm{ESD}$ = bal kamrai végszisztolés átmérő; JK = jobb kamra

A

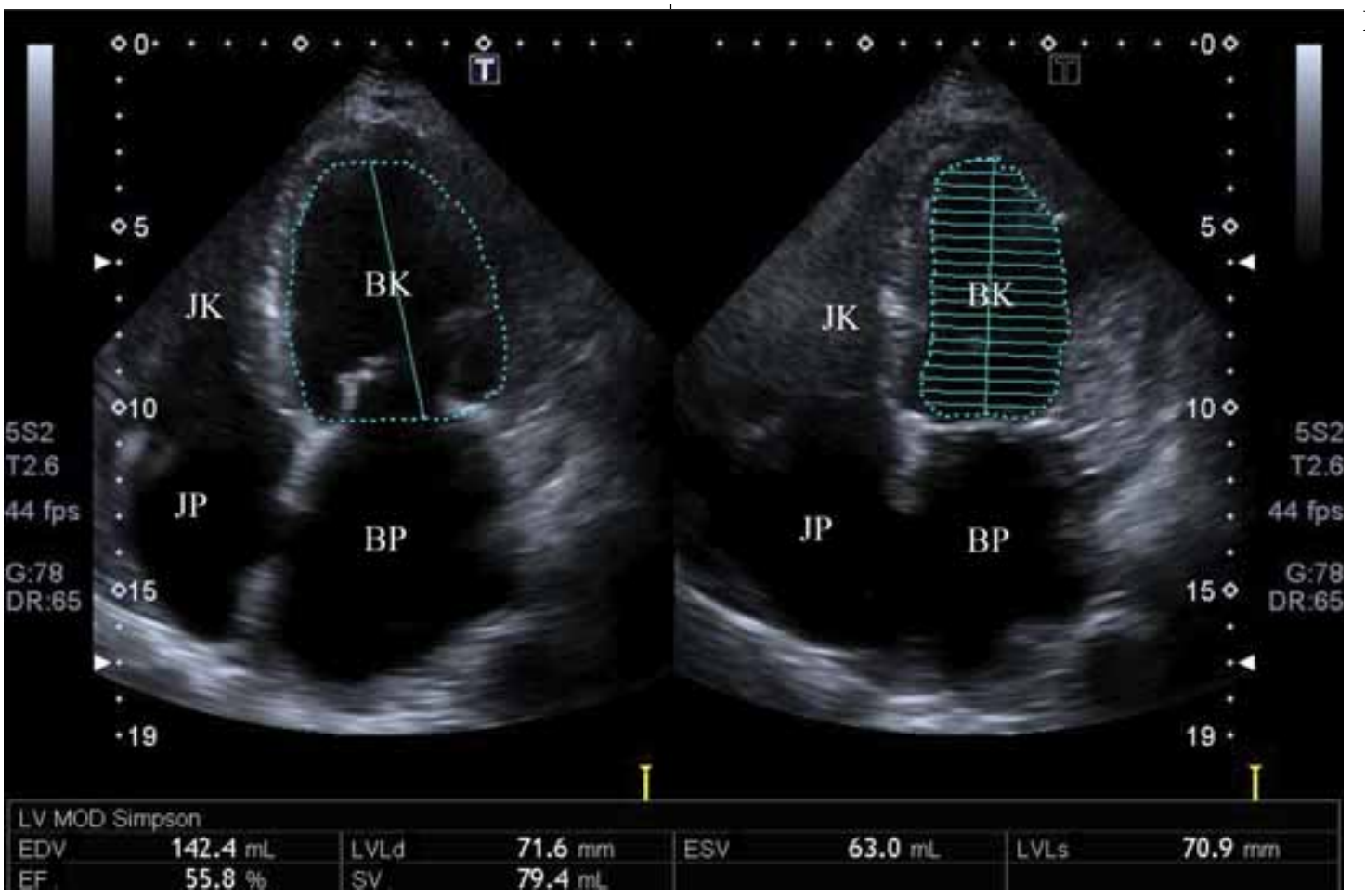

2. ábra $\quad$ A bal kamra vizsgálata módosított Simpson-féle módszerrel apicalisan rögzített 4 üregi (A) és 2 üregi (B) felvételeken. A bal kamra belfelületének diasztolés (A) és szisztolés (B) körberajzolását követóen volumetrikus adatok és ejekciós frakció számítható

$\mathrm{BK}=$ bal kamra; $\mathrm{BP}=$ bal pitvar; $\mathrm{EDV}=$ bal kamrai végdiasztolés térfogat; $\mathrm{EF}=$ bal kamrai ejekciós frakció; $\mathrm{ESV}=$ bal kamrai végszisztolés térfogat; $\mathrm{JK}=$ jobb kamra; JP = jobb pitvar; LVLd $=$ a bal kamra belfelületének hossza diasztoléban; LVLs = a bal kamra belfelületének hossza szisztoléban; $\mathrm{SV}=$ ütötérfogat (stroke volume) 
billentyú záródásának jellegzetes „ívelt” megjelenését kölcsönzi a normális „négyzetes” megjelenés helyett [5].

\section{Fractional area change (FAC) számítása}

A frakcionális areaváltozás a BK-i rövid tengelyi, a papillaris izom szintjén mért diasztolés és szisztolés area értékéből számított paraméter: $\mathrm{FAC}=(\mathrm{EDA}-\mathrm{ESA}) /$ $\mathrm{EDA} \times 100 \%$, ahol az EDA és ESA a végdiasztolés és végszisztolés BK-i areát jelenti (normálérték: >35\%) [5].

\section{* A bal kamrai izomtömeg mérése}

A BK-i átmérő meghatározásával egy időben a BK falainak vastagsága is lemérhető, majd a BK-i izomtömeg (left ventricular mass - LVM) nagysága az alábbi képletek alapján számítható:

$$
\begin{aligned}
\mathrm{LVM}= & 1,05 \times\left[(\mathrm{EDD}+\mathrm{IVS}+\mathrm{PW})^{3}-\mathrm{EDD}^{3}\right] \quad(\text { Troy-féle } \\
& \text { formula }) \\
\mathrm{LVM}= & 1,04 \times\left[(\mathrm{EDD}+\mathrm{IVS}+\mathrm{PW})^{3}-\mathrm{EDD}^{3}\right]-13,6 \mathrm{~g} \\
& (\text { Penn-féle konvenció }) \\
\mathrm{LVM}= & 0,8 \times 1,04 \times\left[(\mathrm{EDD}+\mathrm{IVS}+\mathrm{PW})^{3}-\mathrm{EDD}^{3}\right]+0,6 \mathrm{~g}
\end{aligned}
$$
(American Society of Cardiology konvenció), ahol az IVS és a PW a végdiasztoléban mérhetó interventricularis septum és BK-i hátsó fal (posterior wall) vastagságát jelöli [12]. A módszertan gyors, széleskörüen használt, irodalmi adatokkal alátámasztott mérési módszer. Normális alakú BK (elnyújtott ellipszoid, 2:1 hossz/kereszt metszeti aránnyal) vizsgálatára használható, azonban bizonyos patológiás helyzetekben pontatlan, túlbecsli az LVM-et. Ráadásul az ultrahangnyaláb irányultsága nem mindig megfelelő, és kis mérési hibák nagy pontatlanságot okozhatnak.

A relatív falvastagságot (relative wall thickness - RWT) az alábbi képlettel számíthatjuk: RWT $=(2 \times \mathrm{PW}) / \mathrm{EDD}$. Amennyiben az RWT $\geq 0,42$, az LVM koncentrikus, amennyiben RWT $\leq 0,42$, akkor excentrikus [2].

\section{A bal kamrai rotáció és csavarodás becslése}

Rutinszerúen használható módszertan nem ismert.

\section{A bal kamrai szinkrónia/diszszinkrónia jellemzése}

Számos tanulmányban igazolást nyert, hogy bizonyos echokardiográfiás paraméterek alkalmasak lehetnek a CRT-re kerülő betegek közül azok kiválasztására, akik a későbbiekben reszpondernek bizonyulnak. Bizonyos paraméterek számításakor azonban az egy intézetben végzett (single-center) vizsgálatok nagyfokú pontosságot igazoltak. Komoly csalódást okozott a multicentrikus PROSPECT Trial, mivel igazolást nyert, hogy a korábban bemutatott és széleskörűen alkalmazott, különböző echokardiográfiás módszerrel, köztük MMEvel (valamint kétdimenziós [2DE], Doppler- [DE] és szöveti Doppler- [TDI] echokardiográfiával) számított
12 diszszinkróniát jellemző paraméter nem javítja a CRT-re kerülő betegek kiválasztását a jelenlegi elérhető szakmai vezérfonalakkal (guideline-okkal) szemben [13]. Az ebben a tanulmányban is szereplö, MME-vel számítható, leggyakrabban vizsgált diszszinkróniaparaméter az SPWMD volt (2. táblázat).

\section{Kétdimenziós echokardiográfia (2DE)}

2DE során egy adott síkban vizsgáljuk a szektorba illesztett BK-t a szívciklusnak megfelelően. A módszertan széleskörúen elfogadott és használt, a napi klinikai rutin része. A tanulási fázis relatíve rövid, kivitelezése megfelelő gyakorlat elsajátítását követően gyors. 2DE segítségével különböző nézetek (parasternalis, csúcsi stb.) és metszetek (2, 3 és 4 üregi) készíthetők a BK-ról [5].

\section{A bal kamrai méretek és térfogatok mérése}

\section{*A méretek direkt mérése}

A BK-i méretek direkt módon is lemérhetők a kétdimenziós (2D) csúcsi és parasternalis hossztengelyi és keresztmetszeti képeken, valamint a $2 \mathrm{DE}$ irányításával végzett MME-felvételeken (lásd MME-nél leírtak) [2, 5].

*A módosított Simpson-féle módszer (biplan disk summation) a BK-i térfogatok meghatározására

A BK-i szisztolés funkció egyik legismertebb és leggyakrabban alkalmazott becslési módszere a módosított Simpson-módszer vagy „biplan method of disks” $[2,5]$. Míg az eredeti Simpson-formula a BK-i modellalkotás során a BK-t ideális forgástestekre bontotta fel - egy hengerre, egy csonka kúpra és egy kúpra -, addig a módosított Simpson-féle módszer segítségével számos szeletet lehet a BK-ról létrehozni, majd azokból modellt alkotni. A módszer segítségével AP4CH-ben és apicalis 2 üregi nézetben (apical 2-chamber view - AP2CH) végdiasztoléban és végszisztoléban körberajzoljuk az endocardialis (vér-szövet) határt (2. ábra). A mitralis billentyü szintjében a mitralis ring két szélét egy vonallal összekötjük. A BK hossza ennek a vonalnak és a BK belfelületének legdistalisabb pontját összekötő egyenes távolsága. A vizsgálat során a szoftver a BK-t a hossztengelye mentén egyenlő magasságú hengerek sorozatára osztja, ahol egyes hengerek térfogatát a hengerek magasságának és alapterületének szorzataként számítja. Az alapterület nagyságát az adott helyen mért BK-átmérő értékéből számítja. A végső BK-i térfogatot az egyes hengerek térfogatának összegeként kalkulálja. A módszer lehetőséget teremt „nem ideális” alakú BK esetén a „hibák" figyelembevételére, de ennek ellenére a szívcsúcs megrövidített, az endocardium vagy a síkba nem eső eltérések nem jól detektálhatók lehetnek [2]. A normálértékeket az 1. táblázatban tüntettük fel.

Echokardiográfiás kontrasztanyag használata javasolt, amennyiben kettő vagy több szomszédos endocardialis szegmentum apicalis nézetben gyengén vizualizálható. 
2. táblázat |A diszszinkrónia jellemzésére alkalmazható echokardiográfiás paraméterek

\begin{tabular}{|c|c|c|c|}
\hline Paraméter neve & Rövidítés & Módszer & Számításának módja \\
\hline $\begin{array}{l}\text { Septal-posterior wall } \\
\text { motion delay [13] }\end{array}$ & SPWMD & MME & $\begin{array}{l}\text { A parasternalis rövid tengelyi nézetben mért BK-i septalis és } \\
\text { posterior fali mozgás késésének ideje }\end{array}$ \\
\hline $\begin{array}{l}\text { Interventricular } \\
\text { mechanical delay [13] }\end{array}$ & IVMD & $\mathrm{DE}$ & $\begin{array}{l}\text { A kamrák közötti mechanikus késés során azt vizsgáljuk, hogy a BK } \\
\text { és jobb kamra preejekciós periódusa, nyitódása között mennyi az } \\
\text { időkülönbség (azaz az EKG-n a Q-hullám és a DE során mért aorta } \\
\text { és a pulmonalis artéria kiáramlási görbe kezdete közötti idő } \\
\text { különbsége) }\end{array}$ \\
\hline $\begin{array}{l}\text { Left ventricular filling } \\
\text { time, cardiac cycle length } \\
{[13]}\end{array}$ & $\mathrm{LVFT} / \mathrm{RR}$ & $\mathrm{DE}$ & $\begin{array}{l}\text { A BK telődési idejének (a transmitralis E- és A-hullámok idejének) és } \\
\text { a szívciklushossznak (amely az EKG-n az RR-távolságnak megfelel) } \\
\text { az aránya százalékban }\end{array}$ \\
\hline $\begin{array}{l}\text { Left ventricular preejection } \\
\text { interval }[13]\end{array}$ & LPEI & $\mathrm{DE}$ & $\begin{array}{l}\text { Az EKG-n a QRS kezdete és a DE-vel BK-i ejekció kezdete közötti } \\
\text { idő }\end{array}$ \\
\hline $\begin{array}{l}\text { Left lateral wall } \\
\text { contraction }[13]\end{array}$ & LLWC & $\begin{array}{l}\text { MME- } \\
\text { DE }\end{array}$ & $\begin{array}{l}\text { Az intraventricularis diszszinkrónia jellemzője, amennyiben átfedés } \\
\text { van az MME-vel mért lateralis fali kontrakció vége és a DE-vel mért } \\
\text { BK-i telődés kezdete között }\end{array}$ \\
\hline Ts-(lateral-septal) [13] & - & TDI & $\begin{array}{l}\text { Az ejekciós fázisban a basalis septalis és basalis lateralis } \\
\text { szegmentumok esetén a szisztolés csúcssebesség eléréséhez szükséges } \\
\text { idő különbsége (csúszás) }\end{array}$ \\
\hline $\begin{array}{l}\text { Ts-SD } \\
\text { (Yu-index) [13] }\end{array}$ & - & TDI & $\begin{array}{l}\text { A QRS-től az ejekciós fázisban a szisztolés csúcssebesség eléréséhez } \\
\text { szükséges idő standard deviációja } 12 \text { BK-i szegmentumra } \\
\text { vonatkoztatva ( } 6 \text { basalis és } 6 \text { középső) }\end{array}$ \\
\hline $\begin{array}{l}\text { Peak velocity difference } \\
{[13]}\end{array}$ & PVD & TDI & $\begin{array}{l}\text { A basalis szinten } 6 \text { szegmentumra vonatkoztatva számítjuk, } \\
\text { a csúcssebességek eléréséhez szükséges idők különbsége, amelyet } \\
\text { a maximális és a minimális értékekből számítunk (az izovolumetriás } \\
\text { kontrakció idejére eső sebességértékeket nem vesszük figyelembe) }\end{array}$ \\
\hline
\end{tabular}

Delayed longitudinal
contraction [13]

Ts-peak displacement [13] -

Ts-peak (basal) [13] -

Ts-onset (basal) [13]

A rotáció/csavarodás

jellemzői [24, 28]

Time-to-peak systolic strain [28]
TDI-STE A longitudinális kontrakció késése, amelyet 6 basalis szegmentumnál számítunk szisztolés kontrakciós komponens idején kora diasztoléban TDI-vel és megerősítjük strain rate képalkotással

TDI 4 szegmentumra vonatkoztatott szisztolés elmozdulás (displacement) csúcsáig eltelt idő maximális különbsége

TDI A basalis szinten 6 szegmentumra vonatkoztatott szisztolés csúcssebesség eléréséig eltelt idő maximális különbsége

TDI A basalis szinten 6 szegmentumra vonatkoztatott szisztolés sebesség kezdetéig eltelt idő maximális különbsége

2DSTE A rotáció, csavarodás és torzió értéke, valamint az apicobasalis rotációs csúszás és az aortabillentyú záródásától a BK-i csúcs csavarodásáig eltelt idő is lehet a diszszinkrónia jellemzője (bár meghatározásuk 2DSTE jelenleg nem ajánlott)

2DSTE A szisztolés strain csúcsértékének eléréséhez szükséges idő (time-to-peak systolic strain - TPSS). A szegmentumok közötti időbeli csúszás pontosan lemérhető (legkorábban és legkésőbb aktiválódó régió vagy a septalis és lateralis régió között) és valamennyi strainértékre (radialis, longitudinális, circumferentialis) számítható. A keresztmetszeti képeken jobban használható, mint hossztengelyi metszeteken. A diszszinkrónia jellemezhető továbbá tetszőleges számú (például hat) TPSS standard deviációjának értékével is. Elvileg a fenti paraméterek mintájára „displacement” értékekkel is jellemezhető a BK-i diszszinkrónia

Systolic dyssynchrony

RT3DE

6, 12 vagy 16 BK-i szegmentum esetén a minimális szisztolés térfogat eléréséhez szükséges idők (time-to-minimum systolic volume - TMSV) standard deviációja

Systolic dyssynchrony

3DSTE Az RT3DE-nél leírtaknak megfelelően számíthatjuk valamennyi szegmentumra vonatkoztatva.

3DSTE A 2DSTE-nél leírtaknak megfelelően számíthatjuk valamennyi szegmentumra vonatkoztatva. Irodalmi adatok vannak radialis és 3D strainre vonatkoztatva is
Normálérték

Cutoff $\geq 130 \mathrm{~ms}$

Cutoff $\geq 40 \mathrm{~ms}$

\author{
Cof $\geq 40$ ms
}

Cutoff $\leq 40 \%$

Cutoff $\geq 140 \mathrm{~ms}$

Bármilyen

átfedés

Cutoff $\geq 60 \mathrm{~ms}$

Cutoff $\geq 32 \mathrm{~ms}$

Cutoff $\geq 110 \mathrm{~ms}$

Cutoff $\geq 2$ basalis szegmentum

Cutoff $\geq$ medián

Cutoff $\geq$ medián

Cutoff $\geq$ medián

Cutoff $\geq 10 \%$ 
2. táblázat folytatása

\begin{tabular}{|c|c|c|c|c|}
\hline Paraméter neve & Rövidítés & Módszer & Számításának módja & Normálérték \\
\hline $\begin{array}{l}\text { A longitudinális } \\
\text { „displacement”-hez } \\
\text { szülkséges idöcsúcsok } \\
\text { diszperziója [54] }\end{array}$ & - & 3DSTE & Tizenhat szegmentumra vonatkoztatva számítható & - \\
\hline $\begin{array}{l}\text { Area strain dyssynchrony } \\
\text { index }[55]\end{array}$ & ASDI & 3DSTE & $\begin{array}{l}\text { A csúcs-AS- és a végszisztolés AS-értékek közötti átlagos különbség } \\
16 \text { BK-i szegmentumra vonatkoztatva (nem idő alapján számított } \\
\text { paraméter) }\end{array}$ & - \\
\hline $\begin{array}{l}\text { Apicobasalis rotációs késés } \\
{[56]}\end{array}$ & - & 3DSTE & $\begin{array}{l}\text { A basalis és az apicalis rotáció szinkróniájának megítélése } \\
\text { a csúcsrotációk időkülönbségének meghatározásával történhet }\end{array}$ & - \\
\hline $\begin{array}{l}\text { Rotációs diszperziós index } \\
{[56]}\end{array}$ & RDI & 3DSTE & $\begin{array}{l}\text { A csúcsrotáció eléréséhez szükséges idők standard deviációja } 16 \\
\text { szegmentumra vonatkoztatva }\end{array}$ & - \\
\hline
\end{tabular}

Kontraszt-echokardiográfia során magasabb térfogatértékeket mérhetünk, és ezek az értékek közelebb állhatnak a mágneses rezonanciás vizsgálat (magnetic resonance imaging - MRI), mint arany standard során találtakhoz [14].

\section{*Az area-length módszer a BK-térfogatok meghatá- rozására}

A BK-térfogatok meghatározásának alternatív módszere megtalálható a jelenleg elérhető szakmai irányelvben $[2,5]$. Kivitelezéséhez parasternalis keresztmetszeti képek készítése szükséges a planimetriás mérésekhez (BK area [A]), illetve AP4CH-metszet készítése a BK hosszának leméréséhez a korábban leírtaknak megfelelően (mitralis anulus - apex [L]). A méréseket végdiasztoléban és végszisztoléban is elvégezzük, majd a térfogatot (V) az alábbi képlettel számítjuk: $\mathrm{V}=\left(0,85 \times \mathrm{A}^{2}\right) / \mathrm{L}$. A módszertan előnye, hogy lehetővé teszi az alaki eltérések minimális korrekcióját, de hátránya, hogy a csúcs megrövidített lehet, geometriai feltételezéseken alapul, illetve a módszert támogató publikációk száma limitált.

\section{A BK-i excentricitási index}

A BK-i keresztmetszeti képeken az egymásra meróleges átmérők normális esetben egyformák, arányuk egy. Amennyiben a septum a jobb szívfél terhelése miatt benyomódik, értéke a méretek változása miatt kisebb lesz, mint egy [15].

\section{Egyéb, a klinikumban már kevésbé használt módsze-} rek

\section{A BK-térfogatok meghatározása}

Az úgynevezett „length-diameter” és „bullet” módszerek $[2,5]$.

\section{A bal kamra funkciójának jellemzése}

\section{${ }^{*}$ Ejekciós frakció (EF) mérése}

A szisztolés és diasztolés térfogatok kiszámítását követően az EF a korábban ismertetett képlettel kiszámítható. Jelenleg a módosított Simpson-féle módszertan ajánlott az EF számítására a szakmai irányelv szerint [2]. Ameny- nyiben a BK ábrázolhatósága a képminőség miatt nehézkes, felharmonikus képalkotás (second harmonic imaging - SHI) és echokardiográfiás kontrasztanyag használata (lásd korábban!) jöhet szóba. Gyakorlott vizsgáló számára a globális BK-funkció és az EF vizuális becslése is felmerülhet.

\section{*A regionális falmozgászavarok vizuális becslése}

További lehetőség a BK funkciójának jellemzésére, amennyiben vizuális becslés segítségével ítéljük meg a regionális falmozgások minőségét (wall motion score - WMS): lehet 1. normokinetikus, 2. hipokinetikus (csökkent endocardialis elmozdulás és vastagodás), 3. akinetikus (az endocardialis elmozdulás és vastagodás hiánya) vagy 4 . diszkinetikus (szisztolés „bulging” [kidudorodás] vastagodás nélkül). A jelenleg elérhető szakmai irányelvek az aneurysma külön minősítését nem ajánlja (így a diszkinetikus csoportba sorolja) [2]. Az irodalomban ismert szegmentációs modelleket alkalmazva a BK összes szegmentuma jellemezhető, akár több nézetből is, megkönnyítvén a pontosabb becslést [16]. Ilyenkor a basalis és midventricularis szegmentumok lehetnek anterior, anteroseptalis, inferoseptalis, inferior, inferolateralis és lateralis elhelyezkedésúek. A csúcsi szegmentumok a 16 szegmentum modell esetén anterior, septalis, inferior és lateralis lokalizációjúak lehetnek, míg a 17 szegmentum modell esetén megkülönböztetünk egy csúcsi „sapkát” is. Létezik még egy kevésbé használt 18 szegmentum modell is, amikor valamennyi szinten 6-6 szegmentumot különítünk el [2] (3. ábra).

A wall motion score indexet (WMSI-t) a 16 szegmentumra vonatkoztatott score-ok összegének és a szegmentumok számának arányaként számítjuk, és komoly prognosztikus jelentőséggel bír (2 felett) [7]. Mivel ismert, hogy mely szegmentumot mely coronaria látja el, így adott falmozgászavarból következtethetünk az ischaemiát okozó koszorúérre is. Mivel egyes szegmentumokat más-más koszorúér is elláthat, erre is oda kell figyelni az eredmények elemzésekor:

- A jobb coronaria (right coronary - RC) által ellátott szegmentumok: basalis inferior (BI) és inferoseptalis (BIS) és midinferior (MI) szegmentum. 


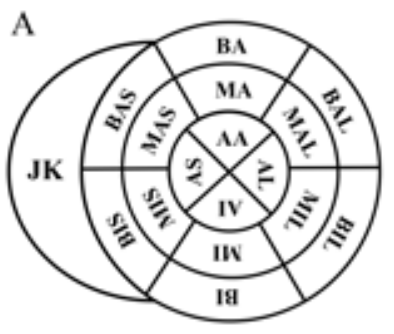

B

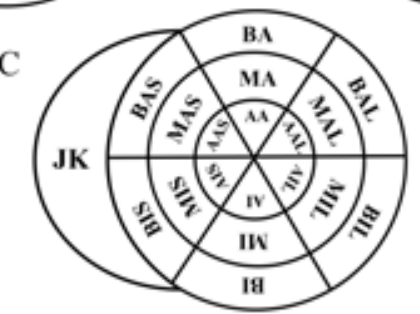

3. ábra

\begin{abstract}
A bal kamra szegmentációjára alkalmazható modellek: a 16 szegmentum (A), a 17 szegmentum (B) és a 18 szegmentum modellek (C)

$\mathrm{Ap}=$ apex $; \mathrm{AA}=$ apicalis anterior $; \mathrm{AAL}=$ apicalis anterolateralis $\mathrm{AAS}=$ apicalis anteroseptalis; $\mathrm{AI}=$ apicalis inferior; $\mathrm{AIL}=$ apica lis inferolateralis; AIS = apicalis inferoseptalis; $\mathrm{BA}=$ basalis anterior; $\mathrm{BAL}=$ basalis anterolateralis; $\mathrm{BAS}=$ basalis anteroseptalis; $\mathrm{BI}=$ basalis inferior; $\mathrm{BIL}=$ basalis inferolateralis; $\mathrm{BIS}=$ basalis inferoseptalis; $\mathrm{JK}=$ jobb kamra; $\mathrm{MA}=$ midanterior $; \mathrm{MAL}=$ mid lateralis; MAS = midanteroseptalis; $\mathrm{MI}=$ midinferior; $\mathrm{MIL}=$ midinferolateralis; MIS = midinferoseptalis
\end{abstract}

- A bal coronaria leszálló szára (left anterior descending

- LAD) által ellátott szegmentumok: basalis anterior (BA) és anteroseptalis (BAS), midanterior (MA) és anteroseptalis (MAS) és apicalis septalis (AS) és anterior (AA) szegmentumok.

- A bal coronaria körbefutó szára (left circumflex LCX) vagy a LAD által ellátott szegmentumok: basalis anterolateralis (BAL), midanterolateralis (MAL) és apicalis lateralis (AL).

- Az LCX vagy RC által ellátott szegmentumok: basalis inferolateralis (BIL) és midinferolateralis (MIL).

- Az RC vagy LAD által ellátott szegmentumok: midinferoseptalis (MIS) és apicalis inferior (AI) szegmentumok.

Amennyiben a BK-i regionális falmozgások ábrázolhatósága a képminőség miatt nehézkes, echokardiográfiás kontrasztanyag és SHI használata itt is szóba jön. A módszertan lényeges limitációja azonban annak szubjektivitása, illetve, ha egy szomszédos szegmentum súlyos falmozgászavart mutat (például diszkinetikus), mivel ilyenkor a mellette levő szegmentum mozgása is kórosnak tûnhet.

\section{A bal kamrai izomtömeg mérése}

Az ajánlások szerint $2 \mathrm{DE}$ során két validált módszertan ajánlott az LVM mérésére: az úgynevezett area-length formula és a „truncated” (csonka kúp) ellipszoid modell $[2,16]$. Mindkét módszernél a myocardialis area kiszámítása a papillaris izom szintjén rövid és hosszten- gelyi metszeteken számított paraméterek segítségével történik bonyolult egyenletek segítségével [2]. A módszerek előnye, hogy kevésbé függnek bizonyos geometrai feltételezésektől, de lényeges hátrányuk, hogy jó képminőség és megfelelő parasternalis keresztmetszeti képek szükségesek a mérésekhez, nehézkes a kivitelezésük, nagy az eredmények variabilitása és kevés az irodalmi adat.

\section{A bal kamrai rotáció és csavarodás becslése}

2DE-alapú módszertan a BK-i rotáció és csavarodás vizsgálatára a klinikumban nem használatos.

\section{A bal kamrai szinkrónia/diszszinkrónia jellemzése}

Rutinszerűen használható módszertan nem használatos.

\section{Doppler-echokardiográfia (DE)}

DE során a Doppler-effektusban rejlő lehetőségeket használjuk ki. Ennek lényege, hogy egy mozgó „tárgyról” visszaverődő hullám frekvenciája (és hullámhossza) megváltozik, amely arányos annak sebességével. Ez a sebességmérésen alapuló módszertan képalkotásra alkalmassá tehető, ahogy azt az évtizedek óta alkalmazott Doppler-technikák bizonyítják (pulzatilis, folyamatos hullámú, színes Doppler). A módszertan a klinikumban ismert, széleskörüen alkalmazott alapeljárásnak tekinthetô [5].

\section{A bal kamrai méretek és térfogatok mérése}

A klinikumban használható módszertan nem ismert.

\section{A bal kamra funkciójának jellemzése}

\section{* Mitralis beáramlási görbe elemzése}

A mitralis billentyưn keresztül a bal pitvarból a BK-ba diasztolében áramló vér sebessége pulzatilis Dopplermódszer segítségével mérhető. A mitralis beáramlási görbe két csúccsal bír: az első hullám a gyors diasztolés telődés fázisában jelentkezik (E-hullám), míg a második a pitvari kontrakciót jellemzi (A-hullám). A mitralis E-hullám deceleratiós idejének (deceleration time - DT) meghatározása és a Valsalva-manőver elvégzése (erőltetett kilégzés zárt száj és orr mellett) fontos jelentőséggel bír a BK-i diasztolés diszfunkció meghatározásában. Az egészségesekben és a diasztolés diszfunkció különböző stádiumaiban látható görbéket a 4 a ábrán tüntettük fel [17].

\section{*A vena pulmonalis áramlásának detektálása}

$\mathrm{Az} \mathrm{AP} 4 \mathrm{CH}$-nézetben rögzítjük a vena pulmonalis áramlási mintáját pulzatilis Dopplerrel (szükség esetén színes 
Normális diasztolés funkció<smiles>[Mg][Mg]</smiles>

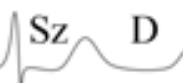

$\mathrm{E} / \mathrm{A}=0,8-1,5 \mathrm{E}$

DT $=160-200$

DE-vel mért mitralis beáramlási görbe

septalis $\mathrm{E}^{\prime} \geq 8$,

TDI-vel mért mitralis anulus elmozdulási sebességértékek pulmonalis vénás áramlás

Egyéb
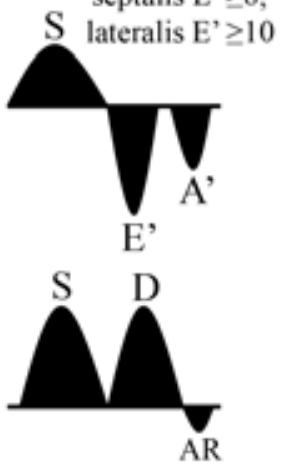

$\mathrm{BP}<34 \mathrm{ml} / \mathrm{m}^{2}$

Ha nagyobb, akkor sportsziv, konstrikció merūl fel
Csökkent

BK-i relaxáció

(I. fokú diszfunkció)

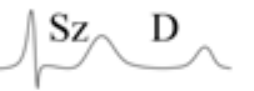

$\mathrm{E} / \mathrm{A}<0,8$

DT $>200$

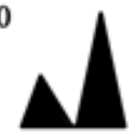

Közepes fokú diasztolés diszfunkció

(pseudonormalizáció,

II. fokú diszfunkció)

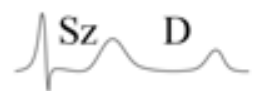

$\mathrm{E} / \mathrm{A}=0,8-1,5$

DT $=160-200$

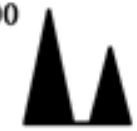

Restriktiv

BK-i telödés

(III. fokú diszfunkció)

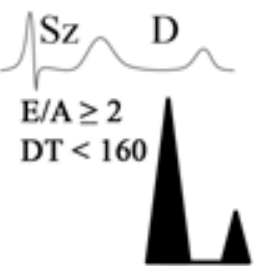

4. ábra $\quad$ A diasztolés diszfunkció stádiumainak jellemzésére alkalmas módszerek (mitralis beáramlási görbe, mitralis anulus elmozdulási sebességértékek, pulmonalis vénás áramlás) a jelenleg elérhető ajánlások alapján

$\mathrm{AR}=$ atrialis reverz áramlás; $\mathrm{BP}=$ bal pitvar; $\mathrm{D}=$ diasztolé $; \mathrm{DE}=$ Doppler-echokardiográfia; $\mathrm{DT}=\mathrm{a}$ transmitralis E-hullám deceleratiós ideje; $\mathrm{E}$ és $\mathrm{A}=$ DE-vel mért transmitralis E- és A-hullám; E' és A' = TDI-vel mért E'- és A'-hullám; S és D = szisztolés és diasztolés áramlás; Sz = szisztolé; TDI = szöveti Doppler-echokardiográfia $\geq$

Doppler segítségével). Szerepét a diasztolés funkció jellemzésében a 4. ábrán tüntettük fel [17].

${ }^{*}$ Myocardial performance index (MPI vagy Tei-index) számítása

A myocardial performance index (MPI) vagy Tei-index a teljes kamrai teljesítményt jellemzi, amelynek számítása során figyelembe veszünk szisztolés és diasztolés paramétereket is: $\mathrm{MPI}=(\mathrm{IVCT}+\mathrm{IVRT}) / \mathrm{ET}$, ahol az IVCT (isovolumetric contraction time) az izovolumetrikus kontrakciós időt, az IVRT (isovolumetric relaxation time) az izovolumetrikus relaxációs időt, az ET (ejection time) az ejekciós időt jelöli (5. ábra). Szisztolés diszfunkcióban az IVCT megnyúlik, az ET lerövidül, az MPI megnő (normálértéke $0,39 \pm 0,05$; kóros, ha $>0,5$ ) [18].

\section{*A bal kamrai dP/dt számítása}

A módszertan lényege a BK-i nyomás emelkedésének jellemzése izovolumetriás kontrakció idején, amely a kontraktilitás nem töltésfüggő jellemzője (6. ábra). A vizsgálat során a mitralis regurgitatióról rögzítünk egy

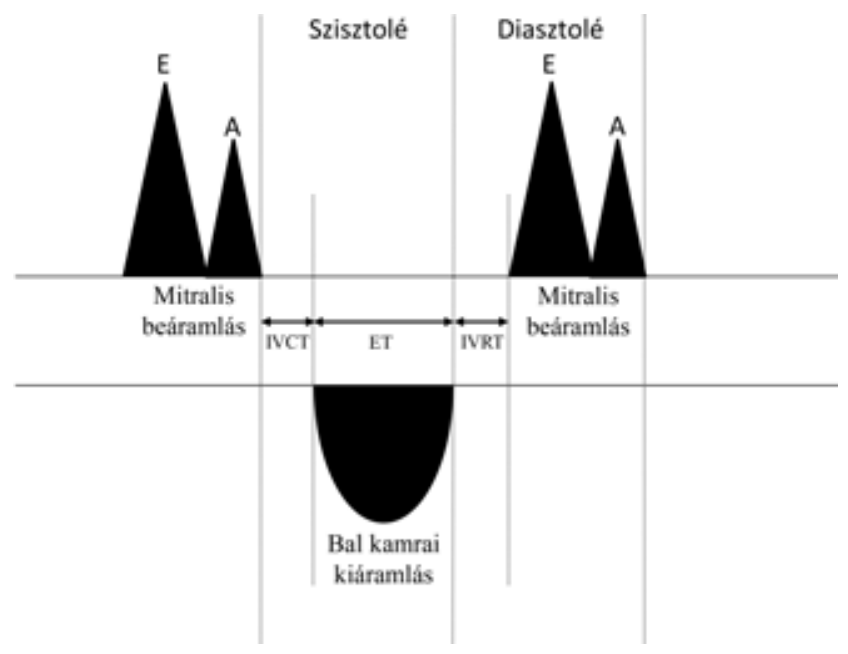

5. ábra A „myocardial performance index” vagy Tei-index számítása Doppler-echokardiográfia segítségével történik a mitralis beáramlás és a bal kamrai kiáramlás figyelembevételével: Tei-index $=(\mathrm{IVCT}+\mathrm{IVRT}) / \mathrm{ET}$

E és A = Doppler-echokardiográfiával mérhető transmitralis Eés A-hullám; ET = ejekciós idő; IVCT = izovolumetrikus kontrakciós idő; IVRT = izovolumetrikus relaxációs idő 


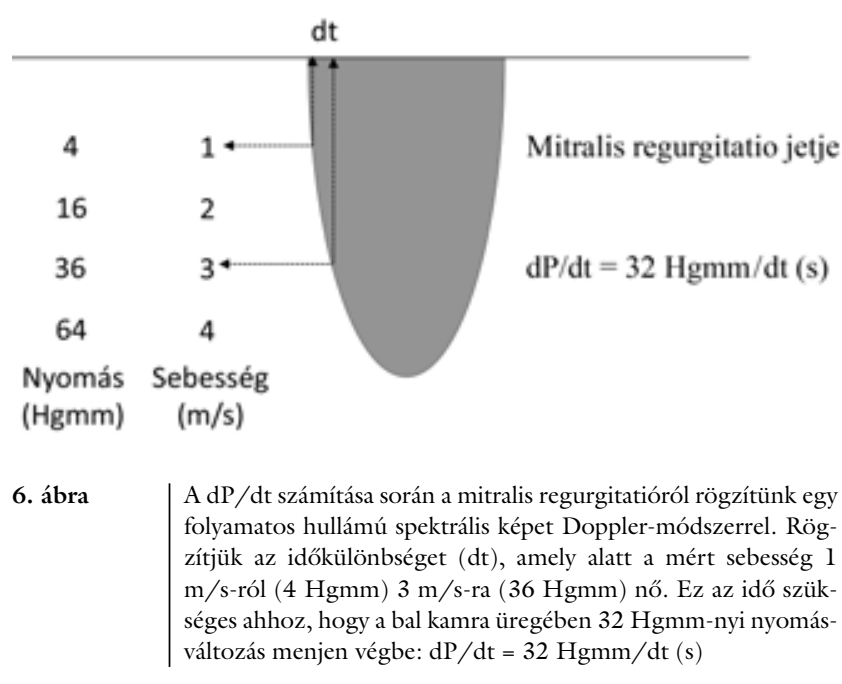

folyamatos hullámú spektrális képet. A dP/dt számításához rögzítenünk kell az időkülönbséget (dt), amely alatt a mért sebesség $1 \mathrm{~m} / \mathrm{s}$-ról $(4 \mathrm{Hgmm}) 3 \mathrm{~m} / \mathrm{s}$-ra $(36$ Hgmm) nő. Ez az idő ahhoz szükséges, hogy a BK üregében $32 \mathrm{Hgmm}$-nyi nyomásváltozás menjen végbe: $\mathrm{dP} / \mathrm{dt}=32 \mathrm{Hgmm} / \mathrm{dt}$ (s) (normálérték: >1000 (1200) $\mathrm{Hgmm} / \mathrm{s})$ [19].

Egyéb, a klinikumban már kevésbé használt módszerek

Az ejekció akcelerációja a bal kamrai kifolyótraktusban (LVOT ACC)

AP3CH- és AP4CH-nézetben pulzatilis Doppler segítségével áramlási mintát rögzítünk a kifolyótraktusban (left ventricular outflow tract - LVOT) $1 \mathrm{~cm}$-re az aortabillentyútől distalisan. A maximális sebesség $\left(\mathrm{V}_{\max }\right)$ és az akcelerációs idő (acceleration time - ACT) könnyen lemérhetô, a paraméter az alábbi képlettel számítható: LVOT ACC $=\mathrm{V}_{\max }(\mathrm{m} / \mathrm{s}) / \mathrm{ACT}$ (s) (ritkán alkalmazott módszer, normálérték: 8-14 m/s²) [20].

Színes M-mód áramlási „propagációs” sebesség $(\mathrm{Vp})$ A mitralis billentyútól az apex felé irányuló áramlás progressziójának sebességmérésére alkalmas módszer, amelyet AP4CH-nézetben színes Doppler használata mellett végzünk. Az M-módot a BK-ba irányuló áramlás közepébe helyezzzük, a Nyquist-limitet megemelve a legnagyobb sebesség kék színben jelenik meg. Az áramlási propagációs sebesség mérésekor (flow propagation velocity - Vp) a korai telődés során mért első aliasing sebesség lejtőjeként mérjük a mitralis billentyú síkjától $4 \mathrm{~cm}$ re distalisan (normálérték: $\mathrm{Vp}>50 \mathrm{~cm} / \mathrm{s}$ ) [17].

\section{A májvénagörbe elemzése}

Bizonyos kórképekben (pl. pericardium betegségei) a májvénagörbe Dopplerrel történő vizsgálata differenciáldiagnosztikus erővel bírhat [17].

\section{A bal kamrai izomtömeg mérése}

Ezzel a módszerrel leírt BK-i izömtömeg-mérési metodika a klinikumban nem használatos.

\section{A bal kamrai rotáció és csavarodás becslése}

DE-alapú módszertan a BK-i rotáció és csavarodás vizsgálatára a klinikumban nem ismert.

\section{A bal kamrai szinkrónia/diszszinkrónia jellemzése}

Számos, DE-vel számítható diszszinkróniaparaméter ismert, azonban a PROSPECT Trialben foglaltaknak megfelelően ezek sem alkalmasak a reszponderek jobb kiválasztására [13]. A DE-vel számítható diasszinkróniaparamétereket a 2. táblázatban részleteztük.

\section{Szöveti Doppler-echokardiográfia (TDI)}

A szöveti Doppler-echokardiográfia (tissue Doppler imaging - TDI) során az alacsony sebességú, de nagy amplitúdójú, hossztengelyi intrinszik myocardialis és anularis sebességértékek mérhetők. A módszertan komoly limitációja, hogy a mért paraméterek szögfüggőek és a kapott értékeket a szomszédos myocardialis szövetek lényegesen befolyásolhatják. Ennek ellenére széleskörúen alkalmazott népszerü technika [21].

\section{A bal kamrai méretek és térfogatok mérése}

Ezzel a módszerrel leírt BK-i volumetrikus mérési metodika a klinikumban nem használatos.

\section{A bal kamra funkciójának jellemzése}

*A mitralis anulus elmozdulási sebességértékeinek mérése

TDI során a mitralis anulus septalisan és lateralisan is vizsgálható, róla jellegzetes hármas deflekció detektálható: kamrai csúcs szisztolés sebesség ( $S^{\prime}$ vagy $S m$ ), korai kamrai csúcs diasztolés sebesség (E' vagy Em) és a pitvari kontrakció sebességértéke (A' vagy Am) (4. és 7. ábra) [17]. S' jól korrelál az EF-fel, míg a normális EF melletti csökkent $S$ ' jó prognosztikus erővel bír. A módszertannak (E/E') a BK-i diasztolés funkcióban betöltött diagnosztikus szerepe ismert (4. ábra). Mivel bizonyos betegekben csak terheléskor észlelhető diasztolés diszfunkció, így diasztolés terheléses vizsgálat elvégzése jöhet szóba [17].

Egyéb, a klinikumban már kevésbé használt módszerek

Myocardial performance index

(MPI vagy Tei-index) számítása

Az MPI a TDI-görbe elemzésével, a DE-nél leírtak analógiájára kiszámítható. 


\section{Strain és strain rate képalkotás}

A „strain” képalkotás lényege egy adott szívüreg egészének (globális) vagy egy adott falrészlet regionális/szegmentális deformációjának jellemzése. Célja a hosszabbodás-rövidülés, vastagodás-vékonyodás jellemzése a szívciklus során. A TDI-mérések során egy adott szövet két szomszédos pontjának sebességét és a két pont közötti relatív távolságot mérjük. Ebből kifolyólag a „strain rate"-t az alábbi képlet segítségével számítjuk: strain rate $=\left(V_{1}-V_{2}\right) / L$, ahol a $V_{1}$ és a $V_{2}$ két különböző pontban mért sebességérték, amelyek távolsága L. TDI során a strain a strain rate értékéből számítható annak időintegráljaként. Strain és strain rate mérések során a myocardialis falmozgás irányának az ultrahangnyaláb irányával egybe kell esnie. Ebből adódóan az elérhetó irodalom többsége a longitudinális strainnel foglalkozik. Mivel a módszer szögfüggoô, és a rutinban a TDI-alapú strain és strain rate mérés nem megfelelő mértékben reprodukálható, a korszerúbb speckle-tracking módszertan van elterjedőben a klinikumban (lásd később!) [22].

\section{A bal kamrai izomtömeg mérése}

Ezzel a módszerrel leírt BK-i izomtömeg-mérési metodika a klinikumban nem ismert.

\section{A bal kamrai rotáció és csavarodás becslése}

Bár bemutattak a BK falában sebességkülönbségek mérésén alapuló módszertant a BK-i rotáció és csavarodás TDI-vel történő vizsgálatára, a napi rutinban használható eljárás nem terjedt el [23].

\section{A bal kamrai szinkrónia/diszszinkrónia jellemzése}

Számos, TDI-vel mérhető diszszinkróniaparaméter ismert az irodalomban, azonban a PROSPECT Trialben foglaltaknak megfelelően ezek sem alkalmasak a reszponderek jobb kiválasztására (2. táblázat) [13].

\section{Kétdimenziós speckle-tracking echokardiográfia (2DSTE)}

A speckle-tracking echokardiográfia (STE) egy olyan kvantifikációs módszer, amelynek segítségével a szívizomszövetről visszaverődő szóródásos echók blokkjait, más szóval természetes akusztikus markereket („speckleket”) használjuk fel a képalkotás során [21]. A konvencionális szürke skálás ultrahangképeken a speckle-k kicsi és fényes képpontként jelennek meg, és olyan struktúrákat jellemeznek, amelyek kisebbek, mint az ultrahang hullámhossza. STE során a myocardium kis területének saját speckle-mintázatát, az úgynevezett „kernel”-t (magot) követi a rendszer képrôl képre a szívciklusnak megfelelően egy speciális algoritmus („block-matching-optical flow method") segítségével, oly módon, hogy hasonló (a legkisebb abszolút különbségú) speckle-mintázatot találjon. Amennyiben ez az analízis 2D echokardiográfia során rögzített egysíkú $2 \mathrm{D}$ felvételeken történik (például $\mathrm{AP} 2 \mathrm{CH}, \mathrm{AP} 4 \mathrm{CH}$, parasternalis keresztmetszeti felvételeken stb.), akkor 2DSTE-ról beszélünk. Ilyenkor a mozgóképeket ideálisan 50-70 kép/s mellett rögzítjük optimális képminőség esetén, kilégzéskor. A módszer előnye, hogy nem szögfüggő, a TDI-hez képest jobban reprodukálható és mütermékek kevésbé befolyásolják. A módszer legfontosabb teoretikus limitációja, hogy mivel egy elmozdulás általában háromdimenziós $(3 \mathrm{D})$, így a vizsgálati síkból kilépő mozgás esetén nem a valóságnak megfelelő értékeket kapunk. Emellett jó minőségú képek rögzítése szükséges az adekvát követések („tracking”) elvégzéséhez [21]. Mindezek ellenére a módszer a korszerú készülékekben elérhető, könnyű kivitelezni és a BK széles körû vizsgálati lehetôségét teszi lehetővé. A módszertan használata során alkalmazandó standardokat az utóbbi időben definiálták [24].

Fontos megemlítenünk egy speciális speckle-tracking alapú eljárást, az úgynevezett velocity vector imaging-et (VVI). Ez a módszertan olyan követo („tracking”) algoritmust használ, amely alkalmas 2D képeken myocardialis sebességek mérésére és ezek vektorként történő ábrázolására. A vektorok iránya a szövet mozgásának irányát jellemzi, míg azok hossza a szöveti sebesség nagyságát. A módszer bizonyos készülékeken elérhető opció, de széleskörúen nem elterjedt [25].

\section{A bal kamrai méretek és térfogatok mérése}

A rövid- és hossztengelyi 2D képeken a méretek direkt módon lemérhetôk, 2DSTE segítségével az apicalis nézetekben idő-BK-i térfogatgörbéket lehet létrehozni a szívciklusnak megfelelően, így végdiasztolés és végszisztolés térfogatok is mérhetők ( 8 . ábra).

\section{A bal kamra funkciójának jellemzése}

Ejekciós frakció (EF) mérése

A fent ismertett módon számított, a szívciklust is figyelembe vevő térfogatértékekből EF számítható.

Sebesség, elmozdulás, strain és strain rate paraméterek számítása

A 2DSTE alkalmas módszernek bizonyult a BK-i deformáció 2D kvantitatív jellemzésére. A leggyakrabban alkalmazott paraméter a Lagrangian-strain, amelyet egy „objektum” egy adott irányban bekövetkező hosszváltozásának és az eredeti hosszának arányaként számítjuk: strain $(\%)=\left(\mathrm{L}_{\mathrm{t}}-\mathrm{L}_{0}\right) / \mathrm{L}_{0}$, ahol az $\mathrm{L}_{\mathrm{t}}$ egy adott $\mathrm{t}$ idópontban mért hossz, míg az $\mathrm{L}_{0}$ az eredeti hossz a 0 idópontban. A leggyakrabban alkalmazott 2DSTE-vel mért paraméter az GLS (global longitudinal strain), amelyet az alábbi képlettel lehet kiszámítani: GLS $(\%)=\left(\mathrm{L}_{\mathrm{S}}-\mathrm{L}_{\mathrm{D}}\right) /$ $L_{D}$, ahol az $L_{S}$ és $L_{D}$ a végszisztolés és végdiasztolés 


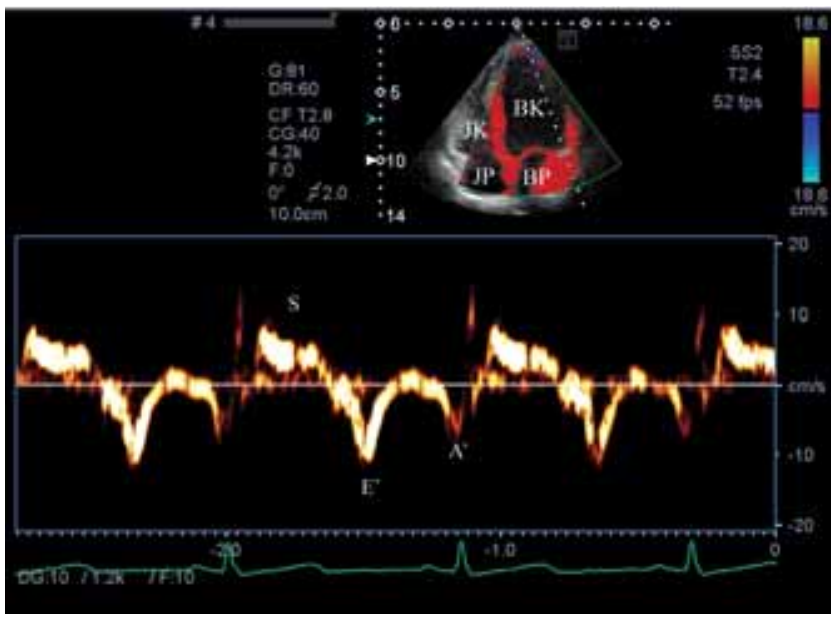

7. ábra

Szöveti Doppler-echokardiográfia során a lateralis anulusról rögzített áramlási kép, amelyen jellegzetes hármas deflekció látható: kamrai csúcs szisztolés sebesség ( $\left.S^{\prime}\right)$, korai kamrai csúcs diasztolés sebesség (E’) és a pitvari kontrakció sebességértéke (A')

$\mathrm{BK}=$ bal kamra; $\mathrm{BP}=$ bal pitvar; $\mathrm{JK}=$ jobb kamra; $\mathrm{JP}=$ jobb pitvar

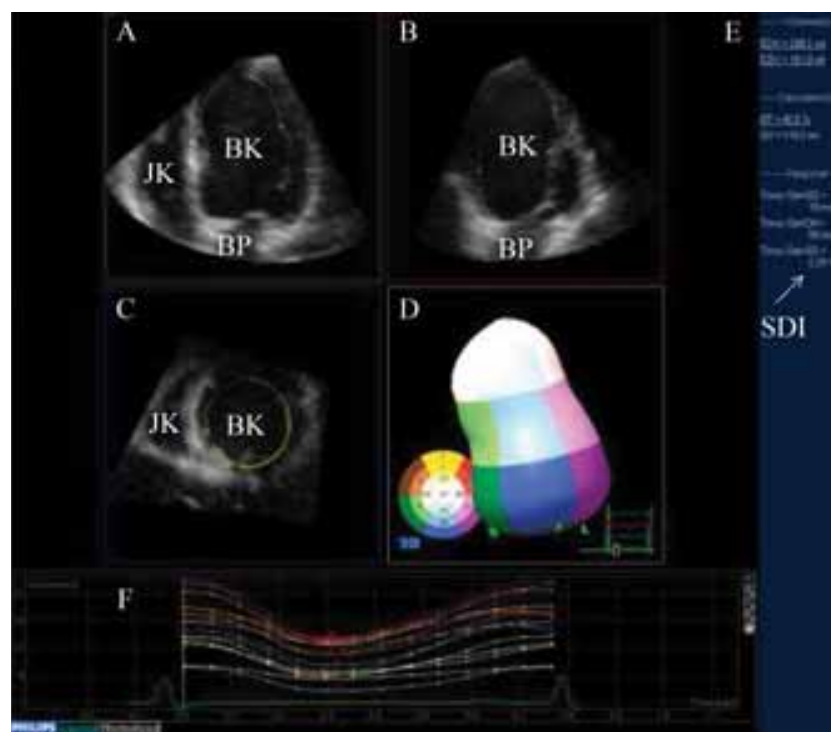

9. ábra

Real-time háromdimenziós echokardiográfia során a rögzített háromdimenziós echóködből speciális szoftverek segítségével kétdimenziós apicalis 4 üregi (A) és 2 üregi (B), valamint keresztmetszeti nézet $(\mathrm{C})$ készíthetô. A módszer segítségével a bal kamra belfelületéról háromdimenziós modell hozható létre (D), amelynek segítségével pontos, a szívciklust is figyelembe vevó végdiasztolés (end-diastolic volume - EDV) és végszisztolés (end-systolic volume - ESV) bal kamrai térfogatok, ejekciós frakció (EF) és ütőtérfogat (stroke volume - SV) számítható (E). Nemcsak a szegmentumokra vonatkoztatott, a szívciklust is figyelembe vevő térfogatváltozás ábrázolható $(\mathrm{F})$, hanem azok időbelisége is, amely időtartamok standard deviációja a diszszinkrónia jele lehet (szisztolés diszszinkrónia index - SDI) (E)

$\mathrm{BK}=$ bal kamra $; \mathrm{BP}=$ bal pitvar $; \mathrm{EDV}=$ bal kamrai végdiaszto lés térfogat; $\mathrm{EF}$ = bal kamrai ejekciós frakció; $\mathrm{ESV}$ = bal kamrai végszisztolés térfogat; $\mathrm{JK}=$ jobb kamra; $\mathrm{JP}=$ jobb pitvar; tmsv = a szisztolés térfogat eléréséhez szükséges idő (time-to-minimum systolic volume); SDI = szisztolés diszszinkrónia index

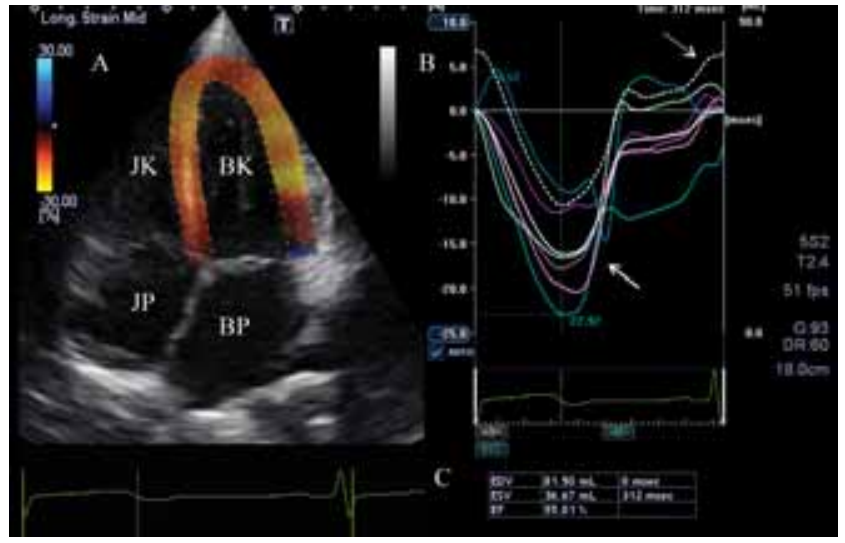

8. ábra

Kétdimenziós speckle-tracking echokardiográfia során a kétdimenziós apicalis 4 üregi felvételen (A) rögzített képen a szegmentális longitudinális strainparaméterek (B), valamint volumetrikus adatok és ejekciós frakció számíthatók (C). A szegmentális strainparaméterek (fehér nyíl) és globális bal kamrai térfogatváltozás (szaggatott nyíl) értékei a szívciklus függvényében jól követhetők (B)

$\mathrm{BK}=$ bal kamra $; \mathrm{BP}=$ bal pitvar; $\mathrm{EDV}=$ bal kamrai végdiasztolés térfogat; $\mathrm{EF}=$ bal kamrai ejekciós frakció; $\mathrm{ESV}=$ bal kamrai végszisztolés térfogat; $\mathrm{JK}=$ jobb kamra; $\mathrm{JP}=$ jobb pitvar

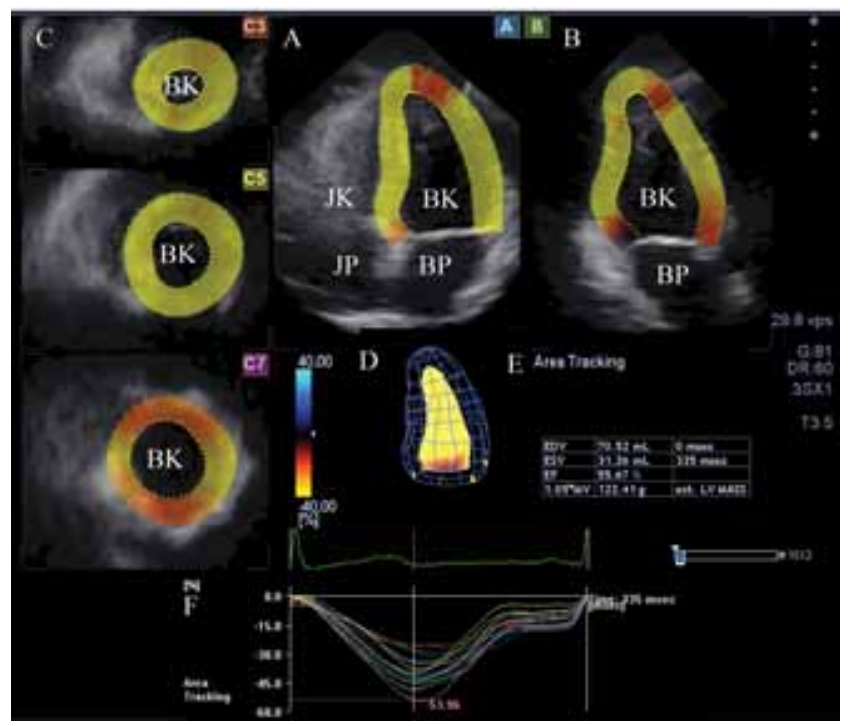

10. ábra $\quad$ Háromdimenziós speckle-tracking echokardiográfia során a háromdimenziós adatbázisból speciális szoftverek segítségével két dimenziós apicalis 4 üregi (A) és 2 üregi (B), valamint a bal kamra különböző szintjein keresztmetszeti metszetek (C) készíthetők. A módszer segítségével a bal kamra belfelületéről háromdimenziós modell hozható létre (D), amelynek segítségével pontos, a szívciklust is figyelembe vevő végdiasztolés (end-diastolic volume - EDV) és végszisztolés (end-systolic volume ESV) bal kamrai térfogatok, ejekciós frakció (EF) és izomtömeg (LV MASS) számítható (E). Nemcsak a szívciklust is figyelembe vevő globális és szegmentális térfogatváltozások, hanem különböző, a vizsgáló által választható strain, „displacement”, rotáció, strain stb. paraméterek is ábrázolhatóvá tehetők (F)

$\mathrm{BK}=$ bal kamra $; \mathrm{BP}=$ bal pitvar $; \mathrm{EDV}=$ bal kamrai végdiasztolés térfogat; $\mathrm{EF}$ = bal kamrai ejekciós frakció; $\mathrm{ESV}$ = bal kamrai végszisztolés térfogat; JK = jobb kamra; JP = jobb pitvar; LV MASS = bal kamrai izomtömeg 
myocardialis hosszt jelöli [2]. Megkülönböztethetünk külön endocardialis, „középfali” (midwall) és átlagolt deformációt is. A jelenlegi technikai ajánlás a strain mellett a longitudinális irányú sebesség, „displacement” (elmozdulás) és strain rate mérését a három apicalis nézetben javasolja elvégezni. A longitudinális mellett radialis és circumferentialis paraméterek is meghatározhatók: az ajánlás a radialis irányú paraméterek mérését a három apicalis nézet mellett a parasternalis keresztmetszeti nézetben, míg a circumferentialis irányúakat csak a keresztmetszeti nézetekben javasolja elvégezni [24]. Az ismert 16 és 17 szegmentum modellt alkalmazva nemcsak a globális, hanem a regionális értékek is meghatározhatók. Tekintettel arra, hogy a 2D és 3D metodikákkal leírt normális strainértékekben nagy szórás mutatkozik, ezek megadásától jelen közleményben eltekintettünk.

A módszertan lehetőséget teremt a falmozgászavarok kvantitatív jellemzésére, akár szubklinikus BK-i deformációs eltérések korai detektálására (lásd még háromdimenziós STE) [26]. A 2DSTE alkalmas lehet bizonyos esetekben kezelések (például kemoterápia) BK-ra kifejtett hatásának, esetleges mellékhatásainak vizsgálatára, továbbkövetéses vizsgálatok elvégzésére [27]. A módszer teoretikus előnye egyszerüsége, azonban hátránya, hogy csak egy adott síkban vizsgálja a BK-t.

\section{A bal kamrai izomtömeg mérése}

2DSTE-vel leírt klinikai mérési metodika a BK-i izomtömeg meghatározására nem használatos.

\section{A bal kamrai rotáció és csavarodás becslése}

Bár keresztmetszeti képeken a circumferentialis sebesség/ strain paraméterekkel együtt rotáció is számítható, a jelenlegi adatok alapján a mérés pontatlansága miatt 2DSTEvel a BK-i rotáció és csavarodás a szakmai irányelveknek megfelelően nem ajánlott [24]. Mindenesetre bizonyos tanulmányok szerint a BK-i „kicsavarodást” (untwistinget) jellemző paraméterek a diasztolés funkciót jellemzik.

\section{A bal kamrai szinkrónia/diszszinkrónia jellemzése}

A 2DSTE során számítható diszszinkrónia-paramétereket a 2. táblázatban tüntettük fel. A velük kapcsolatban elérhető irodalom kevés, további vizsgálatok szükségesek $[24,28]$.

\section{Real-time háromdimenziós echokardiográfia (RT3DE)}

Az RT3DE egy új echokardiográfiás eljárás, amely alig több mint 10 éves múltra tekint vissza $[29,30]$. RT3DE-vizsgálat során úgynevezett mátrixtranszducer segítségével, speciális ultrahangkészülék alkalmazása mellett, olyan piramis alakú háromdimenziós (3D) adatbázist („volume”-t, echóködöt) gyújtünk be digitálisan EKG-kapuzás mellett általunk választható számú szívciklus alatt, amely magában foglalja a szívet vagy annak vizsgálni kívánt részét (jelen esetben a BK-t). Az adatok online vagy késóbb offline elemezhetók. A 3D adatbázisok analíziséhez speciális szoftverek állnak rendelkezésünkre, amelyek segítségével a 2DE-ből ismert apicalis hossz(AP4CH és AP2CH) és keresztmetszeti, valamint rekonstruált 3D képek hozhatók létre. Amennyiben a BK-t szeretnénk vizsgálni, akkor a fent részletezett metszeteken a tér három síkjában történő manuális optimalizálást követően a mitralis anulus végpontjainak és a BK csúcsának szisztolés és diasztolés meghatározását követően a szoftver automatikusan detektálja a 3D-adatbázisban rögzített összes elérhető képen („frame”-en) a BK endocardialis határát szekvenciális analízis segítségével. Így egy, a szívciklusnak megfelelő mozgást végző 3D-modell hozható létre a BK-ról, amelyen volumetrikus mérések végezhetók. A módszertan a nemzetközi irodalomban 2003-ban [29], hazai szinten 2007-ben lett bemutatva [30] (9. ábra). A módszertan jelenleg még bizonyos technikai limitációkkal küzd, beleértve a relatív alacsony térbeli és időbeli felbontóképességet, bizonyos falrészletek csökkent ábrázolhatóságát stb. [30].

\section{A bal kamrai méretek és térfogatok mérése}

Mivel a vizsgálat során egy adott BK-ról készítünk modellt, így a szívciklusnak megfelelő globális (egész BK-ra vonatkoztatott) és szegmentumokra vonatkoztatott térfogatértékek (és egyéb méretek) pontosan megadhatók. Már számos vizsgálat igazolta az RT3DE szerepét a BK-i térfogatok pontos mérésében kontrasztanyag használata mellett és a nélkül [31], függetlenül a vizsgálatok során alkalmazott szoftvertől $[32,33]$. Irodalmi adatok alapján az RT3DE az MRI-hez mérhetố nagy pontosságot és reprodukálhatóságot mutat a BK-i térfogatok mérése során [32, 33].

\section{A bal kamra funkciójának jellemzése}

Ejekciós frakció (EF) mérése

Mivel a BK-i modell segítségével a globális és szegmentális $\mathrm{BK}-\mathrm{i}$ végszisztolés és végdiasztolés térfogatértékek nagy pontossággal meghatározhatók, így globális és az egyes szegmentumokra vonatkoztatott EF is számítható $[31,32,33]$. Echokardiográfiás kontrasztanyag alkalmazása mellett az RT3DE pontosabbnak bizonyult a BKfunkció meghatározásában, amelyet az MRI-hez mérhetô szorosabb korreláció és egyetértés, valamint az alacsonyabb intra- és interobserver variabilitás jellemzett [31]. Mindemellett tény, hogy a szoftverek és azok generációinak különbözősége miatt a térfogatértékek különbözhetnek, így a számított BK-EF értékek is eltéréseket mutathatnak $[32,33]$. 


\section{Falmozgászavarok elemzése}

A falmozgászavarok jellemzése a 2D echokardiográfia során leírtaknak megfelelően vizuális becsléssel történhet, bár a jelenleg elérhető készülékek mellett az esetek többségében a képminőség nem optimális [30]. A BK-i modell segítségével a kereszt- és hosszmetszeti síkok mellett bármilyen, a vizsgáló által választható síkban elemezhetők a falmozgások, ami teoretikusan lehetővé teszi a kisebb (akár rejtett) falmozgászavarok felfedezését. Bizonyos analízisszoftverek segítségével a 3D modellról egy időben kilenc keresztmetszeti síkot is készíthetünk, amelyeket egymás mellé-alá helyezve („iSlice view”) a BK összes szegmentuma egy időben elemezhetővé válik.

\section{A bal kamrai izomtömeg mérése}

Szoftvertől függően több lehetőségünk is van a BK-i izomtömeg korrekt mérésére [30]. A BK-i modell megalkotása során általunk választható tetszőleges számú hossz- és keresztmetszeti síkban a BK falainak (epicardialis és endocardialis) körberajzolását követően a szoftver térbeli („hot dog”-hoz hasonlító) modellt hoz létre, majd ebből kiszámítja az LVM értékét. Egy másik lehetőség, amikor a szoftver automatikusan felkínálja két BKkontúr rajzolását: egyet epicardialisan, míg egy másikat endocardialisan a tér tetszőleges számú síkjában. A két kontúr közé eső területből a szoftver automatikusan kiszámítja az LVM-et. Az RT3DE során nincs szükség geometriai feltételezésre, mivel a mérések során azt rajzoljuk körbe, ami a látható valóság, függetlenül a $\mathrm{BK}$ alakjától. A módszer pontosabb az M-mód és 2D mérési metodikáknál, és az MRI-hez, mint arany standardhoz hasonló pontosságúnak találták az LVM nagyságának kiszámításában [34]. Jelenleg azonban az RT3DE-vel mért normálértékek nem kellően definiáltak, és a vizsgálat függ a képminőségtől, valamint a beteg kooperációjától [2].

\section{A bal kamrai rotáció és csavarodás becslése}

RT3DE-vel leírt metodika a BK-i rotáció és csavarodás mérésére nem ismert.

\section{A bal kamrai szinkrónia/diszszinkrónia jellemzése}

\section{Systolic dyssyncrony index (SDI)}

Az RT3DE során létrehozott 3D térbeli modell segítségével a korábban említetteknek megfelelően a szívciklusnak megfelelően az egyes BK-i szegmentumokra vonatkoztatott úgynevezett idő-térfogat görbék (time-volume curve-ök) rajzolhatók. Amennyiben a BK-i szegmentumok közel egy időben érik el a végszisztolé állapotát, akkor BK-i (intraventricularis) szinkróniáról beszélünk. Ilyenkor az egyes szegmentumokra vonatkoztatott, a végdiasztolétól a végszisztoléig eltelt idő (time-to-minimum systolic volume - TMSV) közel azonos, vagyis azok standard deviációja alacsony. Diszszinkrónia esetén egyes szegmentumok hamarabb, mások később érik el a végszisztolét, vagyis az ehhez szükséges idók (TMSV-k) standard deviációja nagy. Ennek jellemzésére alkalmas a szisztolés diszszinkrónia index (systolic dyssynchrony index - SDI), amelyet általában 6, 12 vagy 16 BK-i szegmentum TMSV-inek standard deviációjaként definiálunk [35] (9. ábra). Bizonyos esetekben az SDI-t az RR időtartamához korrigálják. RT3DE lehetôvé teszi, hogy nemcsak 16 szegmentumra, hanem több száz képpontra vonatkoztatva elemezzük a BK szinkronicitási jellemzőit. Ilyenkor a BK-t kiterítve, körcikkelyként vizsgáljuk (bull's eye imaging), és színkódolás segítségével jellemezzük annak szinkronicitását. A globális végszisztolés képet használván referenciaként, azokat a szegmentumokat, amelyek ehhez képest 30 ms-on belül érik el a minimális térfogatot, a szoftver zölddel kódolja, a korábban aktiválódó helyek kéken, míg a későn aktiválódók piros-sárgán ábrázolódnak. A módszertan teoretikus előnyei a diszszinkrónia megítéléséhez a használata mellett szólnak, de további vizsgálatok szükségesek klinikai használhatóságának igazolására (A cutoff érték: $\geq 10 \%$ ) (2. táblázat).

\section{Háromdimenziós speckle-tracking echokardiográfia (3DSTE)}

A 3DSTE egy, az RT3DE-hez hasonló, de azzal nem öszszekeverendő 3D echokardiográfiás eljárás. A módszer egyesíti a 3D echokardiográfia és az STE előnyeit: a 3D modellalkotás során, a szívciklus időbeliségét is figyelembe vevő térfogatmérések mellett, megteremti a lehetőségét a falmozgászavarok strainalapú kvantifikálásának és rotációs/csavarodási paraméterek számításának. 3DSTE során a képalkotás a 2DSTE-módszertannál leírtaknak megfelelően adott képpontok (speckle-k, echóminták) szívciklusnak megfelelő $3 \mathrm{D}$ követésével történik speciális algoritmus használata mellett. Az 3D adatok begyújtése általunk választható számú szívciklus alatt speciális transzducer és 3DSTE-készülék használata mellett történik. Az adatgyưjtést követően a 3D adatbázis kiértékelése speciális szoftverrel történik AP4CH- és AP2CH-, valamint 3 keresztmetszeti nézetben. Az RT3DE-hez hasonlóan a mitralis anulus végpontjainak és a $\mathrm{BK}-\mathrm{i}$ apexnek az $\mathrm{AP} 4 \mathrm{CH}$ - és AP2CH-nézetekben történt definiálását követően 3D modell hozható létre. A módszertan a hazai irodalomban 2012-ben lett részleteiben bemutatva [36] (10. ábra). A 3DSTE, az RT3DE-hez hasonlóan, alacsony térbeli és időbeli felbontóképességgel bír, amely jelenleg a módszertan egyik fó limitáló tényezője [36].

\section{A bal kamrai méretek és térfogatok mérése}

3DSTE során a 3D modell segítségével a szívciklusnak megfelelő globális és szegmentális BK-i térfogatváltozások nagy pontossággal lemérhetők [37, 38, 39]. A 3DSTE használhatóságát a BK-i térfogatok mérésé- 
ben Nesser és mtsai validálták először, amelyben a 2DSTE-hez képest alacsonyabb inter- és intraobserver variabilitást találtak [37]. Kleijn és mtsai szerint a 3DSTE az MRI-hez képest alulbecsli a BK-i térfogatértékeket [38].

\section{A bal kamra funkciójának jellemzése}

\section{Ejekciós frakció (EF) mérése}

A 3DSTE segítségével létrehozott modell alkalmas a szívciklusnak megfelelő globális és szegmentális EF-értékek számítására [37, 38, 39]. A 3DSTE szoros korrelációt és egyetértést mutat a BK-EF mérésében az MRI-hez, mint arany standardhoz hasonlítva [38]. A szakirodalom szerint a jó intra- és interobserver variabilitás, valamint megfelelő vizsgálati megbízhatóság alkalmassá teheti a módszert a napi rutinban való alkalmazhatóságra [39].

\section{Falmozgászavarok elemzése}

A 2DE-nél, a 2DSTE-nél és az RT3DE-nél leírtaknak megfelelően a falmozgászavarok vizuális becsléssel jellemezhetők, bár a jelenleg elérhető készülék mellett a képminőség nem optimális, és ezzel kapcsolatban eddig lényeges vizsgálat nem történt.

\section{Strainparaméterek számítása}

A 3D modell segítségével nemcsak térfogatértékeket, hanem egy időben strainparamétereket is számíthatunk, amely megteremti a lehetőségét a BK-falak vékonyodásának-vastagodásának kvantitatív jellemzésére. Normális esetben szisztolé során a szegmentumok a BK tengelyének irányában megvastagodnak (radialis strain, RS, pozitív érték), míg hossztengelye és kerülete irányában elvékonyodnak (longitudinális és circumferentialis strain, LS és CS, negatív érték). Saito és mtsai szerint a 3DSTE-vel számított LS kisebb, míg a CS nagyobb, mint a 2DSTEvel kalkulált [40]. A 3DSTE nagy előnye, hogy az úgynevezett unidimenzionális strainparaméterek mellett kombinált strainek is számíthatók. Ilyen a 3D strain (3DS), amely a falvastagodás irányába eső straint jelenti (gyakorlatilag mindhárom fent említett strain kombinációja) és az area tracking/area strain (AS), amikor egy négyzet alakú area követése történik a szívciklusnak megfelelően 3D-ben (gyakorlatilag az LS és CS kombinációja) [41]. A 3DSTE segítségével számos egyéb paraméter mérése is lehetséges, de ezek klinikai jelentősége nem kellően tisztázott (például longitudinális, circumferentialis, radialis és 3D „displacement”). A módszertannal elérhető publikációk száma egyelőre limitált.

A strainparaméterek számításában számos lehetőség rejlik. Egy 3D adatbázis begyújtésével valamennyi fent részletezett paraméter egyidejűleg számítható, és elvileg ezzel az egyszerû vizsgálattal bizonyos esetekben a 2DSTE-hez hasonlóan a szubklinikus BK-i deformáció kvantitatívan jellemezhető, ahogy ezt korai irodalmi ada- tok is alátámasztották [42]. A strainparaméterek számításával lehetőség nyílik a falmozgászavarok vizuális becslésében rejlő szubjektív megítélés minimalizálására. Kleijn és mtsai igazolták, hogy a 3DSTE során számított AS kvantitatív módon jellemzi a vizuális becsléssel igazolt BK-i falmozgászavarok meglétét [43]. Mindamellett az is igazolást nyert, hogy bizonyos paraméterek (például GLS) diagnosztikus erővel bírhatnak a myocardialis infarctus által érintett terület nagyságának diagnosztikájában [44]. A módszertan nagy jövővel bír, azonban további klinikai vizsgálatok szükségesek a számított paraméterek diagnosztikus és prognosztikus értékének tisztázására.

\section{A bal kamrai izomtömeg mérése}

A 3D modell segítségével a térfogat- és strainmérésekkel egy időben elvileg az LVM nagysága is lemérhető az RT3DE-nél ismertetett módon. Jelenleg validációs tanulmány azonban ezzel kapcsolatban még nem született.

\section{A bal kamrai rotáció és csavarodás becslése}

A BK-i rotáció és csavarodás vizsgálatára korábban a TDI, 2DSTE és a teggelt MRI tűnt alkalmasnak. A TDIvel és a 2DSTE-vel történő vizsgálata azonban számos technikai akadállyal küzd, így ezek a módszerek nem terjedtek el. A 3DSTE alkalmas eljárásnak túnik, mivel a térfogat- és strainmérésekkel egy időben, ugyanannak a 3D adatbázisnak a használatával a rotációs és csavarodási (twist, torzió stb.) paraméterek mérhetők. A 3DSTE-t a közelmúltban validálták a $\mathrm{BK}$-i rotáció mérésére állatmodellben [45], és szonomikrometriát használva [46]. Andrade és mtsai szerint a 3DSTE-vel mért BK-i csavarodás értéke kisebb a 2DSTE-vel mérthez képest [47], de a két módszer között szoros korreláció áll fenn a rotációs paraméterek meghatározásában [48].

Fontos annak ismerete, hogy ma még nem tudunk eleget a 3DSTE-vel vizsgált $\mathrm{BK}-\mathrm{i}$ rotációs mechanikáról, a számított paraméterek esetleges diagnosztikus és prognosztikus jelentőségéről. Korai eredmények azt mutatják, hogy a korral együtt mind a basalis, mind az apicalis BK-i rotáció nő, ezáltal a BK-i csavarodás emelkedik, míg a BK-i untwist csökken [49]. Hypertrophiás cardiomyopathia fennállása esetén a BK-i csavarodás nagysága emelkedett, amely elsősorban a megnövekedett apicalis rotációnak köszönhető [50]. Az is igazolást nyert, hogy bizonyos kórképekben a BK-i csavarodás egyszerúen hiányzik [51].

\section{A bal kamrai szinkrónia/ diszszinkrónia jellemzése}

A 3DSTE során az RT3DE-hez hasonlóan a BK szinkronicitásának jellemzéséhez a 3D modell segítségével egy időben valamennyi BK-i szegmentumról információt ka- 
punk. Mai tudásunk szerint számos paraméter jöhet szóba a diszszinkrónia jellemzésére, bár a hozzájuk köthető irodalom kevés, így ezek klinikai jelentősége nem kellően ismert (2. táblázat) $[52,53,54,55,56]$.

\section{Következtetések}

Összefoglalásként megállapítható, hogy ma már számos echokardiográfiás módszer érhető el a napi klinikai gyakorlatban a BK-i méretek, funkció, izomtömeg, csavarodás és szinkrónia jellemzésére. Jelen összefoglaló közleményben csak a klinikumban használható transthoracalis metodikákat összegeztük, a transoesophagealis eljárások és a myocardialis perfúziót becslő kontraszt-echokardiográfiás módszerek ismertetésétől eltekintettünk. Az irodalom állásfoglalása bizonyos paraméterekről és azok értékeiről nem egységes, ezt a tényt figyelembe kell venni közleményünk elolvasásakor. A teljesség igénye nélkül igyekeztünk röviden összefoglalni a klinikumban használható, valamint a még kísérleti stádiumban levő módszereket. A fiatalabb metodikáknál a normál/cutoff értékek ismertetésétől az eredmények diverzitása miatt eltekintettünk. A jelen közlemény nem tekintette céljának a módszerek részletes bemutatását, már csak terjedelmi korlátok miatt sem. Mint látható, bizonyos metódusok szúk lehetôségeket nyújtanak számunkra egy adott BK jellemzéséhez, míg más módszerek a BK széles körü vizsgálatát teszik lehetővé (például 3DSTE). Fontos tudnunk arról, hogy melyik paraméter mikor tud segíteni a klinikai döntéshozatalban, de tudnunk kell arról is, hogy az új metodikák, kiemelten a 3D és STE-eljárások, már itt kopogtatnak az ajtónkon, és várhatóan belátható időn belül a napi rutin részévé fognak válni.

Anyagi támogatás: A közlemény megírása anyagi támogatásban nem részesült.

Szerzői munkamegosztás: N. A., F. T.: A kézirat megszövegezése, irodalmazás. A cikk végleges változatát a szerzők elolvasták és jóváhagyták.

Érdekeltségek: A szerzőknek nincsenek érdekeltségeik.

\section{Irodalom}

[1] Szentágothai, J., Réthelyi, M.: Functional anatomy. Vol. II [Funkcionális anatómia. II. kötet.] Medicina Könyvkiadó, Budapest, 1989. [Hungarian]

[2] Lang, R. M., Badano, L. P., Mor-Avi, V., et al.: Recommendations for cardiac chamber quantification by echocardiography in adults: an update from the American Society of Echocardiography and the European Association of Cardiovascular Imaging. J. Am. Soc. Echocardiogr., 2015, 28(1), 1-39.el4.

[3] Nemes, A., Kalapos, A., Domsik, P., et al.: Left ventricular rotation and twist of the heart. Let's reveal some concepts! [A szív bal kamrai rotációja és csavarodása. Tisztázzunk néhány fogalmat!] Orv. Hetil., 2012, 153(39), 1547-1551. [Hungarian]
[4] Vardas, P. E., Auricchio, A., Blanc, J. J., et al.: Guidelines for cardiac pacing and cardiac resynchronisation therapy. The Task Force for Cardiac Pacing and Cardiac Resynchronization Therapy of the European Society of Cardiology. Developed in collaboration with the European Heart Rhythm Association. Eur. Heart J., 2007, 28(18), 2256-2295.

[5] Feigenbaum, H. (ed.): Echocardiography. 5th ed. Lea \& Febiger, Philadelphia, 1994.

[6] Teichbolz, L. E., Kreulen, T., Herman, M. V., et al.: Problems in echocardiographic volume determinations: echocardiographicangiographic correlations in the presence or absence of asynergy. Am. J. Cardiol., 1976, 37(1), 7-11.

[7] Moller, J. E., Hillis, G. S., Oh, J. K., et al.: Wall motion score index and ejection fraction for risk stratification after acute myocardial infarction. Am. Heart J., 2006, 151(2), 419-425.

[8] Curtis, J. P., Sokol, S. I., Wang, Y., et al.: The association of left ventricular ejection fraction, mortality, and cause of death in stable outpatients with heart failure. J. Am. Coll. Cardiol., 2003, $42(4), 736-742$.

[9] Wandt, B., Bojö, L., Tolagen, K., et al.: Echocardiographic assessment of ejection fraction in left ventricular hypertrophy. Heart, 1999, 82(2), 192-198.

[10] Hu, K., Liu, D., Herrmann, S., et al.: Clinical implication of mitral annular plane systolic excursion for patients with cardiovascular disease. Eur. Heart J. Cardiovasc. Imaging, 2013, 14(3), 205-212.

[11] Ahmadpour, H., Shah, A. A., Allen, J. W., et al.: Mitral E point septal separation: a reliable index of left ventricular performance in coronary artery disease. Am. Heart J., 1983, 106(1 Pt 1), 21-28.

[12] Foppa, M., Duncan, B. B., Robde, L. E., et al.: Echocardiographybased left ventricular mass estimation. How should we define hypertrophy? Cardiovasc. Ultrasound, 2005, 3, 17.

[13] Chung, E. S., Leon, A. R., Tavazzi, L., et al.: Results of the Predictors of Response to CRT (PROSPECT) trial. Circulation, 2008, $117(20), 2608-2616$.

[14] Mulvagh, S. L., Rakowski, H., Vannan, M. A., et al.: American Society of Echocardiography Consensus Statement on the Clinical Applications of Ultrasonic Contrast Agents in Echocardiography. J. Am. Soc. Echocardiogr., 2008, 21(11), 1179-1201.

[15] Jose, J., Nayak, P. R., Krishnaswami, S.: Eccentricity index of the left ventricle 2-D echo study. Indian Heart J., 1987, 39(4), 293297.

[16] Cerqueira, M. D., Weissman, N. J., Dilsizian, V., et al.: Standardized myocardial segmentation and nomenclature for tomographic imaging of the heart. A statement for healthcare professionals from the Cardiac Imaging Committee of the Council on Clinical Cardiology of the American Heart Association. Circulation, 2002, 105(4), 539-542.

[17] Nagueh, S. F., Appleton, C. P., Gillebert, T. C., et al.: Recommendations for the evaluation of left ventricular diastolic function by echocardiography. Eur. J. Echocardiogr., 2009, 10(2), 165-193.

[18] Tei, C., Ling, L. H., Hodge, D. O., et al.: New index of combined systolic and diastolic myocardial performance: a simple and reproducible measure of cardiac function - a study in normals and dilated cardiomyopathy. J. Cardiol., 1995, 26(6), 357-366.

[19] Bargiggia, G. S., Bertucci, C., Recusani, F., et al.: A new method for estimating left ventricular $\mathrm{dP} / \mathrm{dt}$ by continuous wave Doppler-echocardiography: Validation studies at cardiac catheterization. Circulation, 1989, 80(5), 1287-1292.

[20] Baner, F., Jones, M., Shiota, T., et al.: Left ventricular outflow tract mean systolic acceleration as a surrogate for the slope of the left ventricular end-systolic pressure-volume relationship. J. Am. Coll. Cardiol., 2002, 40(7), 1320-1327.

[21] Arias-Godinez, J. A., Guadalajara-Boo, J. F., Patel, A. R., et al.: Function and mechanics of the left ventricle: from tissue Doppler imaging to three dimensional speckle tracking. Arch. Cardiol. Mex., 2011, 81(2), 114-125. 
[22] Opdabl, A., Helle-Valle, T., Skulstad, H. et al.: Strain, strain rate, torsion and twist: echocardiographic evaluation. Curr. Cardiol. Rep., 2015, 17(3), 568.

[23] Notomi, Y., Setser, R. M., Shiota, T., et al.: Assessment of left ventricular torsional deformation by Doppler tissue imaging. Validation study with tagged magnetic resonance imaging. Circulation, 2005, 111(9), 1141-1147.

[24] Voigt, J. U., Pedrizzetti, G., Lysyansky, P., et al.: Definitions for a common standard for $2 \mathrm{D}$ speckle tracking echocardiography: consensus document of the EACVI/ASE/Industry Task Force to standardize deformation imaging. Eur. Heart J. Cardiovasc. Imaging, 2015, 16(1), 1-11.

[25] Tayyareci, ., Yildirimturk, O., Yurdakul, S., et al.: Clinical implications of velocity vector imaging-based two dimensional strain imaging for the evaluation of left ventricular systolic functions. Minerva Cardioangiol., 2010, 58(3), 399-407.

[26] Kalaycioğlu, E., Gökdeniz, T., Aykan, A. C., et al.: The influence of dipper/nondipper blood pressure patterns on global left ventricular systolic function in hypertensive diabetic patients: a speckle tracking study. Blood Press. Monit., 2014, 19(5), 263 270 .

[27] Lange, S. A., Jung, J., Jaeck, A., et al.: Subclinical myocardial impairment occured in septal and anterior LV wall segments after anthracycline-embedded chemotherapy and did not worsen during adjuvant trastuzumab treatment in breast cancer patients. Cardiovasc. Toxicol. (in press)

[28] Nesser, H. J., Winter, S.: Speckle tracking in the evaluation of left ventricular dyssynchrony. Echocardiography, 2009, 26(3), 324 336.

[29] Franke, A., Kübl, H. P.: Second-generation real-time 3D echocardiography: a revolutionary new technology. Medica Mundi, 2003, 47(2), 34-40.

[30] Nemes, A., Geleijnse, M. L., Soliman, O. I., et al.: Real-time 3-dimensional echocardiography - can there be one more dimension? [Real-time 3 dimenziós echokardiográfia - lehet egy di menzióval több?] Orv. Hetil., 2007, 148(52), 2451-2460. [Hungarian]

[31] Krenning, B. J., Kirschbaum, S. W., Soliman, O. I., et al.: Comparison of contrast agent-enhanced versus non-contrast agentenhanced real-time three-dimensional echocardiography for analysis of left ventricular systolic function. Am. J. Cardiol., 2007, 100(9), 1485-1489.

[32] Soliman, O. I., Krenning, B. J., Geleijnse, M. L., et al.: Quantification of left ventricular volumes and function in patients with cardiomyopathies by real-time three-dimensional echocardiography: a head-to-head comparison between two different semiautomated endocardial border detection algorithms. J. Am. Soc. Echocardiogr., 2007, 20(9), 1042-1049.

[33] Soliman, O. I., Krenning, B. J., Geleijnse, M. L., et al.: A comparison between QLAB and TomTec full volume reconstruction for real time three-dimensional echocardiographic quantification of left ventricular volumes. Echocardiography, 2007, 24(9), 967-974.

[34] Yap, S. C., van Geuns, R. J., Nemes, A., et al.: Rapid and accurate measurement of LV mass by biplane real-time 3D echocardiography in patients with concentric LV hypertrophy: comparison to CMR. Eur. J. Echocardiogr., 2008, 9(2), 255-260.

[35] Nemes, A., Geleijnse, M. L., Soliman, O. I., et al.: New method for evaluation of left ventricular dyssynchrony and of the success of cardiac resynchronization therapy: real-time 3-dimensional echocardiography. [Új módszer a bal kamrai diszszinkrónia és a reszinkronizációs terápia sikerességének megítélésére: a real-time háromdimenziós echokardiográfia.] Orv. Hetil., 2009, 150(39), 1834-1838. [Hungarian]

[36] Nemes, A., Kalapos, A., Domsik, P., et al.: Three-dimensional speckle-tracking echocardiography - a further step in the noninvasive three-dimensional cardiac imaging. [Háromdimenziós speckle-tracking echokardiográfia - egy újabb lépés a noninvazív háromdimenziós kardiális képalkotásban.] Orv. Hetil., 2012, 153(40), 1570-1577. [Hungarian]

[37] Nesser, H. J., Mor-Avi, V., Gorissen, W., et al.: Quantification of left ventricular volumes using three-dimensional echocardiographic speckle tracking: comparison with MRI. Eur. Heart J., 2009, 30(13), 1565-1573.

[38] Kleijn, S. A., Brouwer, W. P., Aly, M. F., et al.: Comparison between three-dimensional speckle-tracking echocardiography and cardiac magnetic resonance imaging for quantification of left ventricular volumes and function. Eur. Heart J. Cardiovasc. Imaging, 2012, 13(10), 834-839.

[39] Kleijn, S. A., Aly, M. F., Terwee, C. B., et al.: Reliability of left ventricular volumes and function measurements using three-dimensional speckle tracking echocardiography. Eur. Heart J. Cardiovasc. Imaging, 2012, 13(2), 159-168.

[40] Saito, K., Okura, H., Watanabe, N., et al.: Comprehensive evaluation of left ventricular strain using speckle tracking echocardiography in normal adults: comparison of three-dimensional and two-dimensional approaches. J. Am. Soc. Echocardiogr., 2009, 22(9), 1025-1030.

[41] Ammar, K. A., Paterick, T. E., Khanderia, B. K., et al.: Myocardial mechanics: understanding and applying three-dimensional speckle tracking echocardiography in clinical practice. Echocardiography, 2012, 29(7), 861-872.

[42] Wang, Q., Gao, Y., Tan, K., et al.: Assessment of left ventricular function by three-dimensional speckle-tracking echocardiography in well-treated type 2 diabetes patients with or without hypertension. J. Clin. UItrasound, 2015, 43(8), 502-511.

[43] Kleijn, S. A., Aly, M. F., Terwee, C. B., et al.: Three-dimensional speckle tracking echocardiography for automatic assessment of global and regional left ventricular function based on area strain. J. Am. Soc. Echocardiogr., 2011, 24(3), 314-321.

[44] Wang, Q., Zhang, C., Huang, D., et al.: Evaluation of myocardial infarction size with three-dimensional speckle tracking echocardiography: a comparison with single photon emission computed tomography. Int. J. Cardiovasc. Imaging (in press).

[45] Zhou, Z., Ashraf, M., Hu, D., et al.: Three-dimensional speckletracking imaging for left ventricular rotation measurement: an in vitro validation study. J. Ultrasound Med., 2010, 29(6), 903909.

[46] Ashraf, M., Myronenko, A., Nguyen, T., et al.: Defining left ventricular apex-to-base twist mechanics computed from high-resolution 3D echocardiography: validation against sonomicrometry. JACC Cardiovasc. Imaging, 2010, 3(3), 227-234.

[47] Andrade, J., Cortez, L. D., Campos, O., et al.: Left ventricular twist: comparison between two- and three-dimensional speckletracking echocardiography in healthy volunteers. Eur. J. Echocardiogr., 2011, 12(1), 76-79.

[48] Ashraf, M., Zhou, Z., Nguyen, T., et al.: Apex to base left ventricular twist mechanics computed from high frame rate two-dimensional and three-dimensional echocardiography: a comparison study. J. Am. Soc. Echocardiogr., 2012, 25(1), 121-128.

[49] Tavakoli, V., Sabba, N.: Assessment of age-related changes in left ventricular twist by 3 -dimensional speckle-tracking echocardiography. J. Ultrasound Med., 2013, 32(8), 1435-1441.

[50] Urbano-Moral, J. A., Arias Godinez, J. A., Maron, M. S., et al.: Left ventricular twist mechanics in hypertrophic cardiomyopathy assessed by three-dimensional speckle tracking echocardiography. Am. J. Cardiol., 2011, 108(12), 1788-1795.

[51] Kalapos, A., Domsik, P., Forster, T., et al.: Comparative evaluation of left ventricular function by two-dimensional echocardiography and three-dimensional speckle-tracking echocardiography in noncompaction cardiomyopathy. Result from the MAGYARPath Study. [A kétdimenziós echokardiográfia és a háromdimenziós speckle-tracking echokardiográfia összehasonlító vizsgálata a balkamra-funkció megítélésében noncompaction cardiomyopathiában. Eredmények a MAGYAR-Path Tanulmányból.] Orv. Hetil., 2013, 154(34), 1352-1359. [Hungarian] 
[52] Kang, Ү., Sun, M. M., Cui, J., et al.: Three-dimensional speckle tracking echocardiography for the assessment of left ventricular function and mechanical dyssynchrony. Acta Cardiol., 2012, $67(4), 423-430$.

[53] Tanaka, H., Hara, H., Saba, S., et al.: Usefulness of three-dimensional speckle tracking strain to quantify dyssynchrony and the site of latest mechanical activation. Am. J. Cardiol., 2010, 105(2), 235-242.

[54] Li, C. H., Carreras, F., Leta, R., et al.: Mechanical left ventricular dyssynchrony detection by endocardium displacement analysis with 3D speckle tracking technology. Int. J. Cardiovasc. Imaging, 2010, 26(8), 867-870
[55] Tatsumi, K., Tanaka, H., Tsuji, T., et al.: Strain dyssynchrony index determined by three-dimensional speckle area tracking can predict response to cardiac resynchronization therapy. Cardiovasc. Ultrasound, 2011, 9, 11.

[56] Matsumoto, K., Tanaka, H., Tatsumi, K., et al.: Left ventricular dyssynchrony using three-dimensional speckle-tracking imaging as a determinant of torsional mechanics in patients with idiopathic dilated cardiomyopathy. Am. J. Cardiol., 2012, 109(8), 11971205 .

(Nemes Attila dr., Szeged, Semmelweis u. 6., 6725 e-mail: nemes.attila@med.u-szeged.hu)

\title{
MEGHÍl ó
}

\section{A Szent Margit Kórház Intézeti Tudományos és Kutatás Etikai Bizottsága tisztelettel meghívja az érdeklődőket a következő tudományos ülésére.}

\author{
Időpont: 2015. október 29. (csütörtök) 14.30 óra
}

A rendezvény helyszíne: Szent Margit Kórház - Budapest III., Bécsi út 132. „A" épület, I. emelet, Konferenciaterem

Üléselnök: Prof. Dr. Berényi Marianne

\section{Előadások}

Dr. Boér Katalin: Ono-teamek: az onkológusok és társszakmák szemszögéből

Dr. Árvay Tünde: Kemoterápiák okozta hematológiai mellékhatások: lázas neutropenia, anémia, thrombocytopenia

Dr. Farczádi Enikő, Dr. Haller István: Fájdalomcsillapítás a daganatos betegeknél

Minden érdeklődőt szeretettel várunk! 